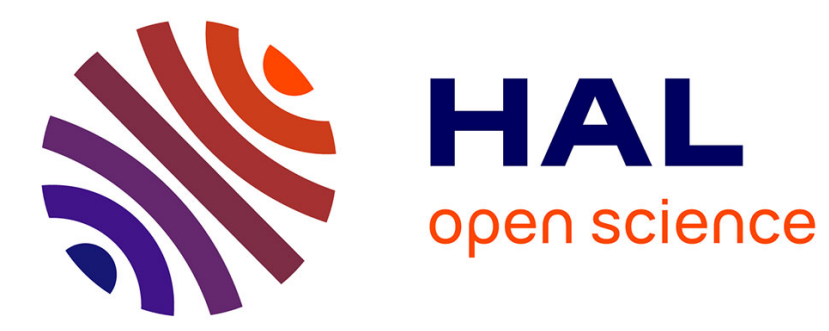

\title{
Effect of climatic environment on feed efficiency in swine
} David Renaudeau, Hélène Gilbert, Jean Noblet

\section{To cite this version:}

David Renaudeau, Hélène Gilbert, Jean Noblet. Effect of climatic environment on feed efficiency in swine. Feed efficiency in swine, Wageningen Academic Publishers, pp.183-210, 2012, 978-90-8686-7561. 10.3920/978-90-8686-756-1_9. hal-01210313

\section{HAL Id: hal-01210313 \\ https://hal.science/hal-01210313}

Submitted on 6 Jun 2020

HAL is a multi-disciplinary open access archive for the deposit and dissemination of scientific research documents, whether they are published or not. The documents may come from teaching and research institutions in France or abroad, or from public or private research centers.
L'archive ouverte pluridisciplinaire HAL, est destinée au dépôt et à la diffusion de documents scientifiques de niveau recherche, publiés ou non, émanant des établissements d'enseignement et de recherche français ou étrangers, des laboratoires publics ou privés. 


\section{Feed efficiency in swine}

edited by:

John F. Patience

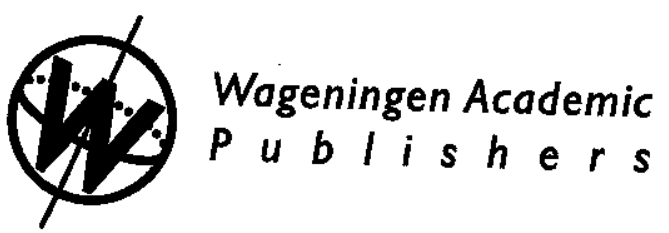





\title{
9. Effect of climatic environment on feed efficiency in swine
}

\author{
D. Renaudeau', H. Gilbert ${ }^{2}$, and J. Noblet ${ }^{3}$ \\ 'INRA, UR143, Animal Production Unit, F-97170 Petit Bourg, France \\ ${ }^{2}$ INRA, UMR 444, Cell Genetics Laboratory, F-31326 Toulouse, France \\ 3INRA, UMR 1348, Physiology, Environment and Genetics for the Animal and Livestock Systems, \\ F-35590 Rennes, France
}

\begin{abstract}
Since feed costs comprise about 60 to $70 \%$ of the total costs of production, efforts to reduce feed costs is then a major preoccupation for increasing competitiveness of the pig industry. Understanding the factors that affect feed conversion in pigs can enable producer to more effectively combine various inputs in order to achieve a low feeding cost. There are many factors involved in reaching good feed efficiency including genetic, diet, feed, management, housing and environment. Temperature is the single most important environmental factor affecting the global farm feed efficiency. In ad libitum fed animals, changes in metabolic heat production are essential mechanisms to maintain body temperature within a physiologically safe range under cold or heat stress. These adjustments have direct consequences on energy intake and/or maintenance requirements which in turn could reduce energy efficiency as conversion of feed to tissue or other products. However, the low level of performance related to a thermal challenge can also be attributed to a direct effect of ambient temperature (independent of feed intake) on reproductive physiology, health, and energy metabolism. Finally, thermal stress could also be a major cause of pig mortality at birth, during the nursing period or thereafter, and could predispose pigs to mortality or morbidity by other causes (starvation, diseases, etc.). High mortality rates in nursing piglets or in finishing pigs have a significant impact on overall farm feed efficiency. The chapter describes how climatic environment impacts feed efficiency in pigs and reviews solutions that can be used in order to attenuate the effect of environmental temperature on feed efficiency.
\end{abstract}

\section{Introduction}

In pig production, 50 to $70 \%$ of the total production costs are due to feed expenses. The reduction of feeding costs is then a major preoccupation for increasing competitiveness of the pig industry, especially when cost of feedstuffs shows dramatic augmentations and (or) fluctuations. Thus, feed efficiency is an important determinant of profitability for swine producers and small increments/ deteriorations in this trait can have a major economic impact. The overall feed efficiency of a pig farm is a complex trait which combines the sow's feed utilization to produce piglets and the pig's feed utilization to produce meat during the growing-finishing phase. As a consequence, feed efficiency depends upon a lot of factors such as (1) nutritional factors (the quantity, the composition, and the digestibility of feed), (2) animal factors (breed, sex, age, body weight), and (3) environmental factors (management, health and climate). Climatic factors can be considered as one of the main limiting environmental factors of feed efficiency both in reproductive sows and in growing pigs. The increasing concerns on production losses due to thermal cold or heat stress is justified not only for the coolest and the hottest periods of the year in temperate countries but 


\section{Effect of climatic environment on feed efficiency in swine}

As the amount of RE depends both on the amount of $M E$ above maintenance $\left(M E_{i}-M E m\right)$ and the partial efficiency of its utilization for growth $\left(\mathrm{k}_{\mathrm{g}}\right)$, FCR can also be expressed as follows (Henry and Noblet, 1986; Noblet et al., 1994b):

$\mathrm{FCR}=(1 /[\mathrm{ME}]) \times\left(1 / \mathrm{k}_{\mathrm{g}}\right) \times[\mathrm{E}]_{\mathrm{ADG}} \times(\mathrm{FL} /[\mathrm{FL}-1])$

where $\mathrm{FL}$ is the feeding level $\left(\mathrm{ME}_{\mathrm{i}}\right.$ as a multiple of maintenance requirement).

This equation shows the well-known effects of energy density and energy content of BW gain (or body composition) on FCR. But it also indicates that FCR is reduced with increased FL and according to a curvilinear relationship with a sharp increase of FCR at energy intakes close to the maintenance level and a small decrease at very high feed intakes. A reduced FCR can then be achieved by raising the $\mathrm{ME}$ intake and/or by reducing the maintenance requirement (MEm). However, according to the curvilinear relationship between FL and $\left[\mathrm{E}_{\mathrm{ADG}}\right]$, the reduction of FCR with the increase of $\mathrm{FL}$ is attenuated, especially when MEi increases above ME required for maximal protein deposition. Under ad libitum conditions and if adequate feed is used, it is assumed that climatic factors, especially hot climatic conditions, have small effects on intake $(\mathrm{kg})$ (D. Renaudeau, unpublished results) Therefore, the effects of climatic conditions on FCR should be envisaged according to both their effects on body composition and feed intake relative to the maintenance energy requirements.

\section{Thermoregulation and energy utilization}

Pigs are homeothermic animals as they can maintain body temperature within narrow limits under varying environmental thermal conditions by balancing heat loss and heat production (HP).The relationships between ambient temperature ( $\mathrm{Ta}$ ) and the balance between heat loss and heat production is schematically illustrated in Figure 1. According to Mount et al. (1974), the thermoneutral zone is defined as the Ta range above which, at a fixed level of energy intake, heat production is minimal and constant. The lower and upper limits of the thermoneutral zone are called the lower (LCT) and upper (UCT) critical temperatures, respectively. In thermoneutral conditions, heat production is related to the utilization of metabolisable energy (ME) for maintenance and productive processes. At maintenance, total $\mathrm{ME}$ intake is converted into heat as the energy retention is nil. The contribution of maintenance HP to total body HP varies with the level of production averaging 70 to $72 \%$ in the growing pig (Noblet et al., 1999), 90 to $92 \%$ in the pregnant sow (Noblet et al., 1997), and 65\% in the lactating sow (Noblet and Etienne, 1987). Heat associated with the productive processes results from the synthesis of new tissues (muscle and fat tissues, fetal tissues, milk) from $\mathrm{ME}$ above maintenance. The amount of heat generated for tissue deposition depends on the partition of $\mathrm{ME}$ into protein and lipids synthesis and on the biochemical origin of nutrients used for meeting the requirements. In fact, the energetic efficiency (net energy to $\mathrm{ME}$ ratio) for protein deposition is lower than for lipid deposition (60 vs. 80\%; Van Milgen et al., 2000) and the efficiency of utilization of ME for $\mathrm{NE}\left(\mathrm{k}_{\mathrm{g}}\right)$ varies with dietary characteristics: the $\mathrm{k}_{\mathrm{g}}$ value is higher for starch $(82 \%)$ and fat $(90 \%)$ than for crude protein (CP; 60\%) or dietary fiber (60\%) (Noblet et al., 1994a). In other words, the amount of HP that will be dissipated in the environment will be higher in high $\mathrm{CP}$ or fiber diets than in high starch or fat diets. These variations in thermic effect of diet (TEF) are used to formulate diets adapted to different Ta situations (see below). 


\section{Renaudeau, H. Gilbert, and J. Noblet}

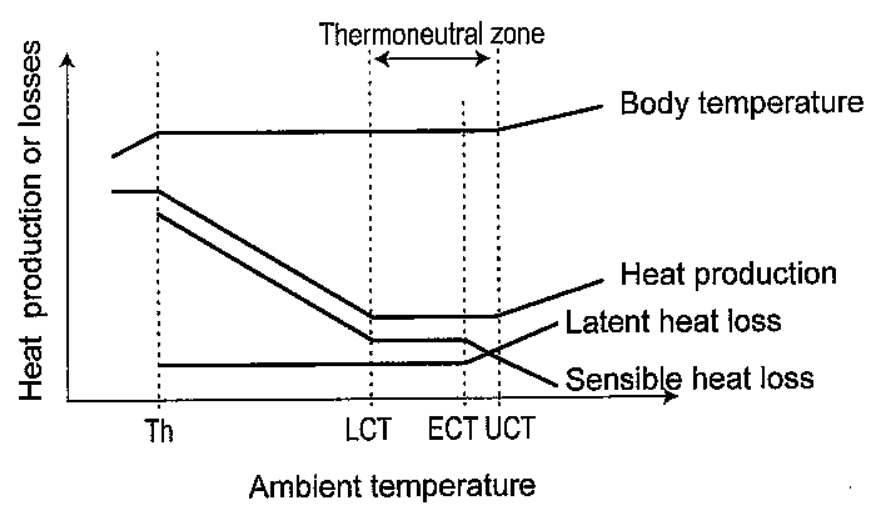

Figure 1. Diagrammatic representation of the relation between heat production or heat losses and body temperature as affected by ambient temperature (adapted from Mount et al., 1974). Th, LCT, ECT, and UCT are threshold temperatures for hypothermia, lower, evaporative and upper critical temperatures, respectively.

Ambient temperature affects both total heat loss and the partition between latent (evaporative) and sensible heat loss. In thermoneutral conditions, body temperature is maintained constant through some adjustments in heat losses. Between the LCT and the evaporative critical temperature (ECT), sensible heat loss is predominant. This loss mainly depends on the thermal gradient between the animal surface and the contacting surface (surrounding air for radiation and convection, and the floor or other animals for conduction). In both cases, the body surface area that is in contact with the surrounding environment also plays a crucial role in heat loss process. Below LCT, the sensible heat losses increase as a consequence of the increased thermal gradient between animal surface and surrounding environment, and the only way for the animal to maintain homeothermy is to increase the rate of heat production. The maintenance of a high metabolic rate below LCT is closely dependent on both availability of energy substrate (body reserves, energy intake) and the ability of the animal to utilize these substrates as an energy source (Le Dividich et al., 1998). When Ta is below the hypothermia threshold, the summit metabolic rate is reached and the animal cannot compensate for the high rate of heat loss, so body temperature falls and sooner or later, the body temperature decreases and the animal dies (Curtis, 1983).

Above the ECT, the increase in Ta makes sensible heat transfer less effective because of the reduction of the required minimal thermal gradient between the skin and the surrounding environment. Due to the fact that the pig has relatively few functional sweat glands, the major component of the increase in evaporative heat loss is through increased respiratory rate. Skin evaporation can also occur by passive processes, especially when the pig can have access to a wallow. The efficiency of both respiratory and skin evaporative heat loss depends on the vapor pressure gradient between the animal and the environment. As a consequence, in tropical humid climates, the evaporative heat losses are less efficient, which accentuates the effect of heat stress on pig performance. When Ta increases above the UCT, the pig can no longer control its body temperature. Therefore, the increase in body temperature causes an increase in the metabolic rate 


\section{Effect of climatic environment on feed efficiency in swine}

(due to the Van't Hoff effect) which causes an increase in HP which in turn results in a further increase in body temperature until the lethal temperature is reached (Curtis, 1983). For instance, the lethal rectal temperature for a $50 \mathrm{~kg} \mathrm{BW}$ pigs is about $42{ }^{\circ} \mathrm{C}$ on average, but it is variable between animals (Figure 2).

For the purpose of animal production, the determination of the lower and upper limits of the thermoneutral zone is of major importance because this zone represents the temperature range over which the efficiency of energy utilization is maximum and the energy available for tissue deposition is optimal. Little information exists on the thermoneutral zone in pigs, especially for UCT values (Table 1). In contrast, studies on LCT are well documented. It depends on many factors, including animal factors (breed, body weight, physiological stage, thermal insulation), management factors (feeding level, group size), and environmental factors (relative humidity, air movement, radiant heat, floor type, sanitary status) (Close and Clark, 1981; Noblet et al., 2001). In general, LCT decreases as the body weight and the thermal insulation increase or when the feeding level is increased.

In the following parts of this chapter, the term 'thermal stress' will refer to thermal conditions for which Ta is lower than LCT or higher than UCT.

\section{Consequences of thermal stress on feed efficiency}

Physiological and metabolic adjustments resulting from the thermoregulatory responses to a thermal stress have negative consequences on pig productivity and health. In ad libitum fed animals, changes in metabolic heat production (HP) are essential mechanisms to maintain body temperature within a physiologically safe range under cold or heat stress. These changes have direct consequences on energy intake and/or maintenance requirements which in turn could reduce energy efficiency as conversion of feed to tissue or product. However, the low level of performance related to a thermal challenge can also be attributed to a direct effect of Ta

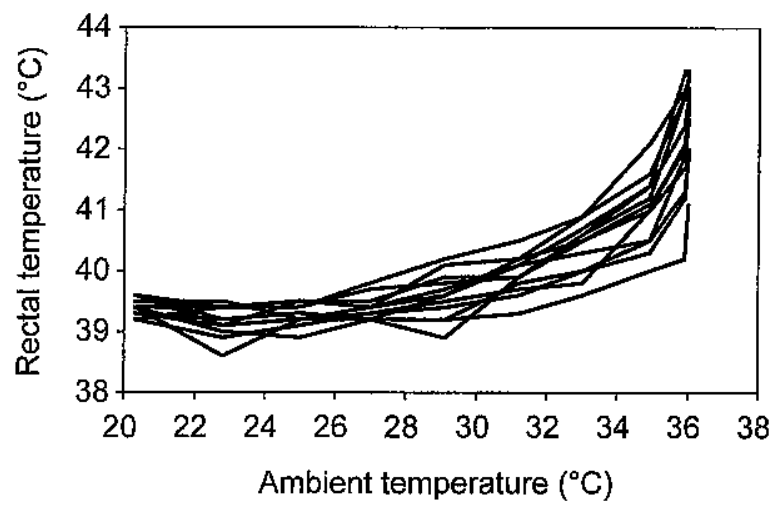

Figure 2. Change in body temperature from thermoneutrality to lethal ambient temperature in $50 \mathrm{~kg} \mathrm{BW}$ Large White pigs housed in individual crates (D. Renaudeau, unpublished results). 


\section{Renaudeau, H. Gilbert, and J. Noblet}

Table 1. Values of critical temperature according to the physiological stage and the housing conditions.

\begin{tabular}{|c|c|c|c|c|c|c|}
\hline \multirow[t]{2}{*}{ Class of pigs } & \multirow[t]{2}{*}{ Housing } & \multirow[t]{2}{*}{ Age/BW } & \multicolumn{4}{|c|}{ Critical temperature $\left({ }^{\circ} \mathrm{C}\right)$} \\
\hline & & & Th & $\mathrm{LCT}$ & ECT & UCT \\
\hline \multirow[t]{3}{*}{ Newborn piglets } & individually & $1 \mathrm{~d}$ & $13^{\prime}$ & $34^{1}$ & - & - \\
\hline & individually & $2 d$ & $10^{1}$ & $30^{1}$ & & $31-33^{2}$ \\
\hline & group & $2 d$ & - & $26^{3}$ & & \\
\hline Nursing piglets & group & $3-4 \mathrm{~kg}$ & - & $20^{3}$ & & \\
\hline \multirow[t]{2}{*}{ Weaned piglets } & individually & $28 \mathrm{~d}$ & - & $30^{4}$ & & \\
\hline & group & $28 \mathrm{~d}$ & - & $27^{5}$ & & \\
\hline \multirow[t]{6}{*}{ Growing/finishing pigs } & individually & $20 \mathrm{~kg}$ & - & $19^{6}$ & $28^{7}$ & $30^{6}$ \\
\hline & group & $20 \mathrm{~kg}$ & - & $17^{6}$ & & \\
\hline & individually & $60 \mathrm{~kg}$ & - & $18^{6}$ & $26-27^{8,9}$ & $29^{6}$ \\
\hline & group & $60 \mathrm{~kg}$ & - & $16^{6}$ & $25^{10}$ & \\
\hline & individually & $100 \mathrm{~kg}$ & - & $17^{6}$ & $24^{11}$ & $29^{6}$ \\
\hline & group & $100 \mathrm{~kg}$ & - & $15^{6}$ & & \\
\hline \multirow[t]{2}{*}{ Pregnant sows } & individually & - & - & $21^{12,13}$ & & $30^{2}$ \\
\hline & group & - & - & $14^{13}$ & & $30^{2}$ \\
\hline Lactating sows & individually & - & - & $12^{14}$ & $25^{15}$ & $27^{15}$ \\
\hline Boars & individually & - & - & $20^{16}$ & - & - \\
\hline
\end{tabular}

1 Berthon et al. (1994), ${ }^{2}$ Holmes and Close (1977), ${ }^{3}$ Kovacs and Rafai (1973), ${ }^{4}$ Rinaldo and Le Dividich (1991),

${ }^{5}$ Le Dividich et al. (1980), ${ }^{6}$ Adapted from Holmes and Close (1977) for an average ME intake equal to $\times 2.5 \mathrm{ME}$ for maintenance ${ }^{7}$ Ingram (1964), ${ }^{8}$ Brown-Brandl et al. (2001), ${ }^{9}$ Renaudeau et al. (2007), ${ }^{10}$ Huynh et al. (2005), ${ }^{11}$ Comberg et al. (1972), ${ }^{12}$ Noblet et al. (1989), ${ }^{13}$ Geuyen et al. (1984), ${ }^{14}$ Black et al. (1993), ${ }^{15}$ Quiniou and Noblet (1999), ${ }^{16}$ Kempet al, (1989).

(independent of feed intake) on reproductive physiology, health, and energy metabolism. Finally, thermal stress could also be a major cause of pig mortality at birth, during the nursing period or thereafter, and could predispose pigs to mortality or morbidity by other causes (starvation, diseases, etc.). High mortality rates in nursing piglets or in finishing pigs have a significant impact on overall farm feed efficiency.

\section{Young pigs}

It is well established that pre-weaning mortality has serious economic impact on a sow's feed efficiency. Currently, up to $20 \%$ of live born piglets do not survive from the onset of farrowing to weaning at 28-d age and this proportion tends to increase with hyper prolific sows (Le Dividich, 2006). Piglet mortality comprises stillbirths and live-born piglets that die before weaning. Stillborn piglets represent 5 to $7 \%$ of total born and die during farrowing or immediately after farrowing as a result of asphyxiation or soon after birth since they have been weakened by the birth process (Herpin et al., 1996). During the last two decades, the number of stillborn piglets 


\section{Effect of climatic environment on feed efficiency in swine}

has increased with selection for litter size, limiting the effectiveness of selection for this trait (Canario et al., 2006). From a survey conducted in Belgium, when Ta in the farrowing room exceeds $22^{\circ} \mathrm{C}$ at the time of parturition, the risk of stillbirth increases significantly (Figure 3). Similar results were reported in tropical areas (Yang et al., 1996; Renaudeauet al., 2003b). The related prolonged farrowing duration at high Ta would explain the increased number of stillbirths. However, appropriate supervision of births and provision of assistance to weaker piglets could help to save many pigs (Herpin et al., 1996).

Many reports have been conducted to examine the causes of pre-weaning mortality (Le Dividich, 2006). Crushing by the sow, starvation, infection or abnormalities are immediate causes of mortality with, in most surveys, crushing by the sow and starvation being more frequent (Varley, 1995). Pre-weaning mortality increases with litter size, lighter pigs being at a particular risk (Herpin et al., 2002). At birth, the piglet experiences a dramatic change in the Ta of its new surroundings. In comparison with the homeostatic temperature in the sow uterus ( 38 to 40 ${ }^{\circ} \mathrm{C}$ ), the piglets are usually born into a much cooler environment $\left(20\right.$ to $22^{\circ} \mathrm{C}$ ) (Kammersgaard et al., 2011). In addition, the ability of the piglet to conserve heat is very limited because the piglet is virtually hairless, devoid of subcutaneous fat, and wet with fetal fluids. Although a warm environment is usually provided in the farrowing pen using various heat systems, the piglets are relatively unable to detect it during the first day. In practice, as the Ta of the farrowing room is much lower than its LCT and close to the temperature for which the metabolic rate is maximal, the newborn piglet experiences a dramatic period of cold stress until it displays an efficient thermoregulatory response consisting essentially in the ability to locate itself in the heated area or close to the udder, to huddle, and to consume sufficient amounts of colostrum and milk (Le Dividich et al., 1998). The maintenance of a high metabolic rate during this period of cold stress is closely dependent on both the availability of energy substrate and the ability of the newborn pig to utilize these energy sources. The requirement for energy is met by mobilization of energy body reserves (glycogen and fat) and by colostrum ingestion. As the fat content of newborn piglet is very low when compared to most other mammalian newborns (Mellor and

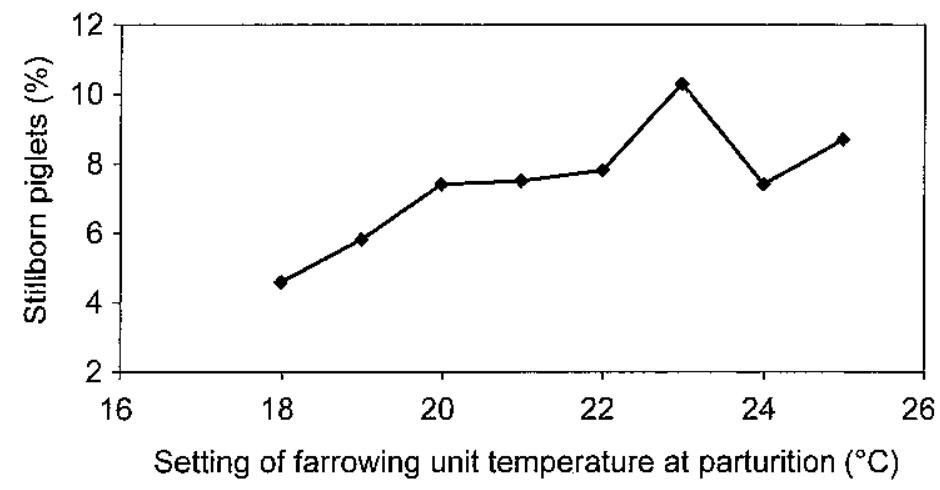

Figure 3. Effect of farrowing unit ambient temperature at parturition on the mean percentage of stillborn piglets (adapted from Vanderhaeghe et al., 2010). 


\section{Renaudeau, H. Gilbert, and J. Noblet}

Cockburn, 1986), most of the energy from the body reserves is derived from glycogen stored in the liver and skeletal muscles. As the depletion rate of the glycogen reserves is rapid after birth, colostrum rapidly becomes the main source of energy for thermoregulation. The thermogenic importance of colostrum is illustrated by Noblet and Le Dividich (1981) who reported a positive relationship between metabolic heat production and the amount of colostrum intake by piglets kept at $18{ }^{\circ} \mathrm{C}$ during the first day postpartum. The colostrum intake is $27 \%$ lower at 18 to $20^{\circ} \mathrm{C}$ compared to that at 30 to $31^{\circ} \mathrm{C}$ (Le Dividich and Noblet, 1981) with detrimental consequences on the acquisition of passive immunity and energy supply for sustaining a high metabolic rate. However, factors related to the piglet such as low birth weight and poor vitality also influence the consumption of colostrum and therefore they are crucial for piglet survival. Noblet et al. (2001) summarized the complex etiology of piglet mortality and the central role of cold stress on this analysis in Figure 4.

From 2 days of age to weaning, the improvement of piglet's thermal insulation, related to the increase in peripheral fat accretion, reduces the LCT and decreases its susceptibility to cold stress. In addition, in the presence of a supplemental heat source in the farrowing pen, the piglet fully expresses its thermoregulatory behavior with a reduced metabolic extra-thermoregulatory heat demand (Noblet et al., 2001). During the nursing period, piglet BW gain is mainly related to sow milk production and, to a lesser extent, on the amount of additional feed (solid/liquid) intake (Pluske et al., 1995).

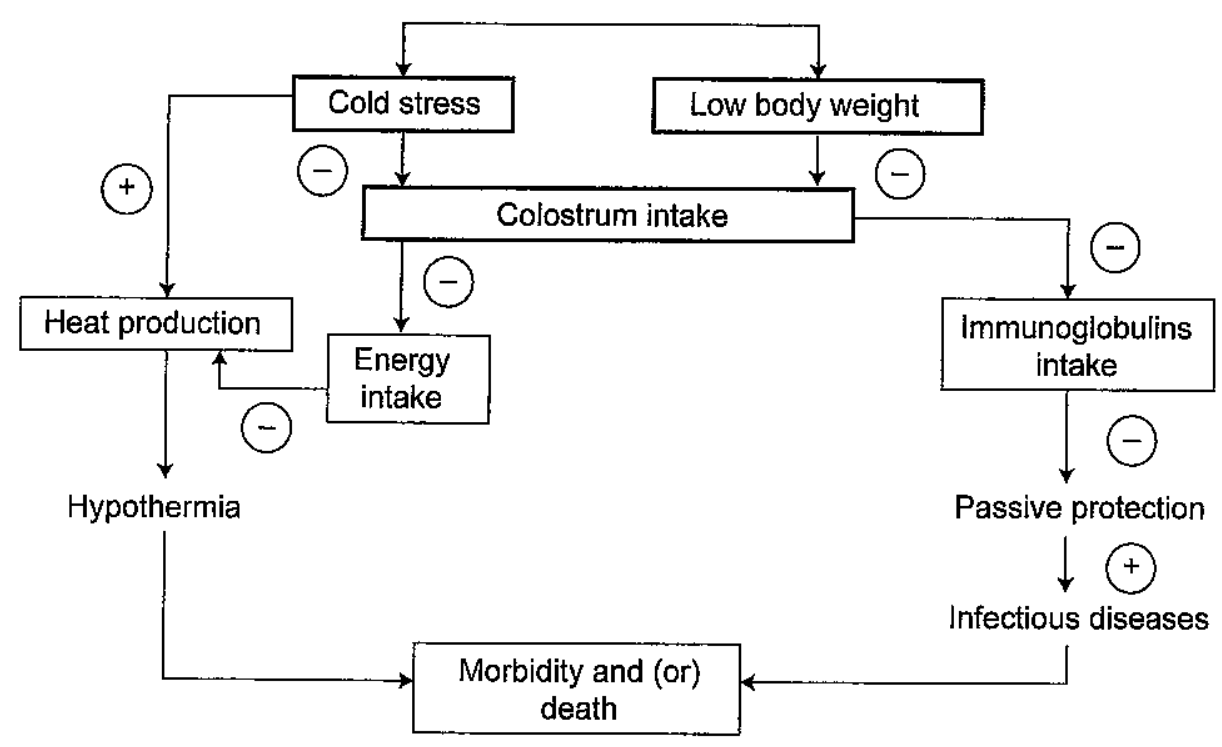

Figure 4. Representation of the possible effects of cold stress and low birth weight on the health of the neonatal pig (Noblet et al., 2001). 


\section{Effect of climatic environment on feed efficiency in swine}

\section{Post̂-weaning, and growing-finishing pigs}

The period following weaning between 3 and 4 weeks of age is characterized by rapid changes in environmental components of the piglets in relation to changes in feed intake and feed composition, metabolism, and tissue thermal insulation (Le Dividich and Herpin, 1994). This period is an important time in the life of the pig, one which has significant impact on future performance (Tokach et al, 1992). Under most commercial situations, weaning results in simultaneous stress including separation from the sow and mixing of the litters, changes in housing and climatic environment and in diets. This feeding transition is generally associated with a critical period of underfeeding leading to reduced feed efficiency and growth rate. The related low feeding level elevates the newly-weaned pig's thermal requirements (Le Dividich, 1999). On average, the LCT is about 26 to $28^{\circ} \mathrm{C}$ during the first week post weaning and it decreases down to $23-24^{\circ} \mathrm{C}$ in the second week post weaning (Close, 1987). This means that after the critical period corresponding to about the first two weeks after weaning, Ta can be reduced by 2 to $3{ }^{\circ} \mathrm{C} /$ week until the temperature to be maintained in the finishing house is reached. During this period, the pig is to some extent able to compensate for a suboptimum environment by increasing its voluntary feed intake.

In growing-finishing pigs fed nutritionally adequate diets, feed efficiency mainly depends on the level of feed or energy intake, the maintenance requirement, and the efficiency with which $\mathrm{ME}$ above maintenance is used for growth. Changing feed intake is an efficient strategy used by the animal to cope with changes in Ta. These variations in energy intake have direct and indirect effects on energy deposition.

In ad libitum feeding conditions, pigs adjust their energy intake to compensate for the effect of changes in Ta. In practice, changes in energy intake vary according to the duration and the intensity of the thermal challenge. For example, when pigs are challenged with a chronic thermal stress, changes in feed intake occur within the 3 to 6 days after the onset of the cold or the hot thermal challenge (Verhagen et al., 1988; Renaudeau et al., 2010). According to a quantitative analysis of data published in the literature, our results show a curvilinear decrease in feed intake with an increase in Ta (Figure 5). For a $50 \mathrm{~kg}$ BW pig, feed intake decreases at a rate of $8 \mathrm{~g} / \mathrm{d} /{ }^{\circ} \mathrm{C}$ from 16 to $24^{\circ} \mathrm{C}$ and then at a rate of $46 \mathrm{~g} / \mathrm{d} /{ }^{\circ} \mathrm{C}$ from 24 to $32{ }^{\circ} \mathrm{C}$. Over the same Ta range, feed intake is reduced by 30 and $70 \mathrm{~g} / \mathrm{d} /{ }^{\circ} \mathrm{C}$, respectively for a $75 \mathrm{~kg} \mathrm{BW}$ pig. In addition, the threshold temperature at which feed consumption starts to decrease is reduced when $\mathrm{BW}$ increases (Renaudeau et al., 2011b). This larger susceptibility in heavier pigs is mainly related to a lower ability to dissipate heat (lower surface area-to-mass ratio, high backfat thickness). In our meta-analysis approach, we pointed out that a large variability existed among studies regarding the effect of Ta on feed intake. As suggested by Le Dividich et al. (1998), this high variability is explained by numerous factors including breed, degree of body fatness, diet composition, sanitary status, and other climatic factors (humidity, draught, etc.). In addition, pre-experimental rearing conditions and their potential related effects on the animal response to heat stress during the experimental period could be an additional source of variation. Differences in the experimental protocol between studies (e.g. duration of acclimation period to temperature, treatment before the experimental period) could aIso explain some of this variability. Under practical housing conditions and especially under tropical conditions where buildings are often semi-opened, pigs 


\section{Renaudeau, H. Gilbert, and J. Noblet}
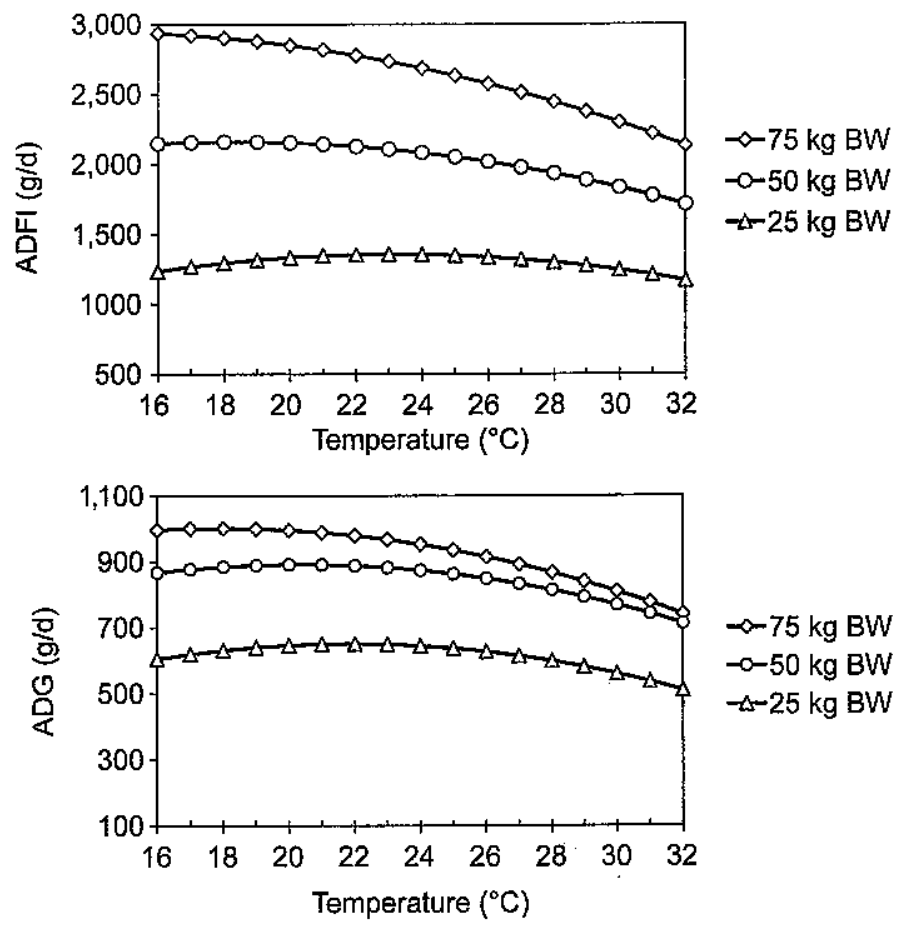

$\curvearrowright 75 \mathrm{~kg} \mathrm{BW}$

$-\infty 50 \mathrm{~kg} \mathrm{BW}$

$-a-25 \mathrm{~kg} B W$

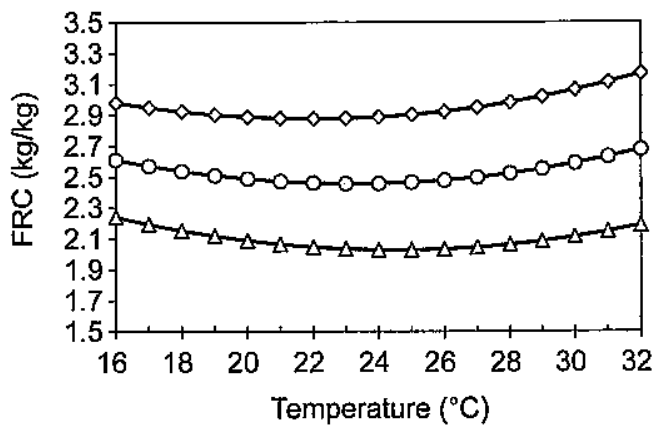

$\prec-75 \mathrm{~kg} \mathrm{BW}$

$-0-50 \mathrm{~kg} \mathrm{BW}$

$-2-25 \mathrm{~kg} \mathrm{BW}$

Figure 5. Effect of ambient temperature and pig BW on daily feed intake (ADFI, g/d), average daily gain (ADG, $\mathrm{g} / \mathrm{d}$ ) and feed conversion ratio (FRC, $\mathrm{kg}$ feed/kg gain) (adapted from Renaudeau et al., 2011).

are usually subjected to fluctuations in Ta within a day or over successive days. Consequently, the application of results collected in closely controlled and constant environments may be inappropriate when applied to variable Ta conditions. In fact, some evidence shows that pigs are partially capable of maintaining feed consumption when exposed to a cycling diurnal Ta challenge. For example, pigs maintained in a hot, cyclic $\mathrm{Ta}$, partially shift their feeding activity to the cooler periods of the day to minimize the detrimental effect of high Ta on feed intake (Feddes et al., 1988; Renaudeau $e t$ al., 2006). However, in growing-finishing pigs, the extra feed consumed during the cooler period 


\section{Effect of climatic environment on feed efficiency in swine}

of the day can compensate for the reduced feed intake during the hot periods of the day as long as the temperature variation does not exceed $\pm 1.5^{\circ} \mathrm{C}$ (Quiniou et al., 2000a).

As shown for feed intake, responses of ADG and FCR to Ta are curvilinear and they are both strongly affected by pig BW (Figure 5).According to Rinaldo and Le Dividich (1991) and Nienaber et al. (1987), the Ta range for which the ADG is maximal is 15 to $25^{\circ} \mathrm{C}$ in young pigs and 10 to $20^{\circ} \mathrm{C}$ in growing-finishing pigs, respectively (Figure 6). The corresponding values for a minimal FCR are 25 to $30^{\circ} \mathrm{C}$, and 20 to $25^{\circ} \mathrm{C}$, respectively. Under cold conditions, the ADG and FCR decrease at rates of $8 \mathrm{~g} / \mathrm{d} /{ }^{\circ} \mathrm{C}$ and $0.040 /{ }^{\circ} \mathrm{C}$ from 18.5 to $12.0{ }^{\circ} \mathrm{C}$ in young pigs and $5 \mathrm{~g} / \mathrm{d} /{ }^{\circ} \mathrm{C}$ and $0.052 /{ }^{\circ} \mathrm{C}$ from 15 to $5^{\circ} \mathrm{C}$ in growing finishing pigs (Figure 6). In addition, under cold conditions, the energy content of the BW gain ([E] $]_{\text {gain }}$ ) remains constant in young pigs between 25 and $15^{\circ} \mathrm{C}$ (Rinaldo and Le Dividich, 1991) whereas it increases $+22 \mathrm{kcal} / \mathrm{kg} /{ }^{\circ} \mathrm{C}$ for growing finishing
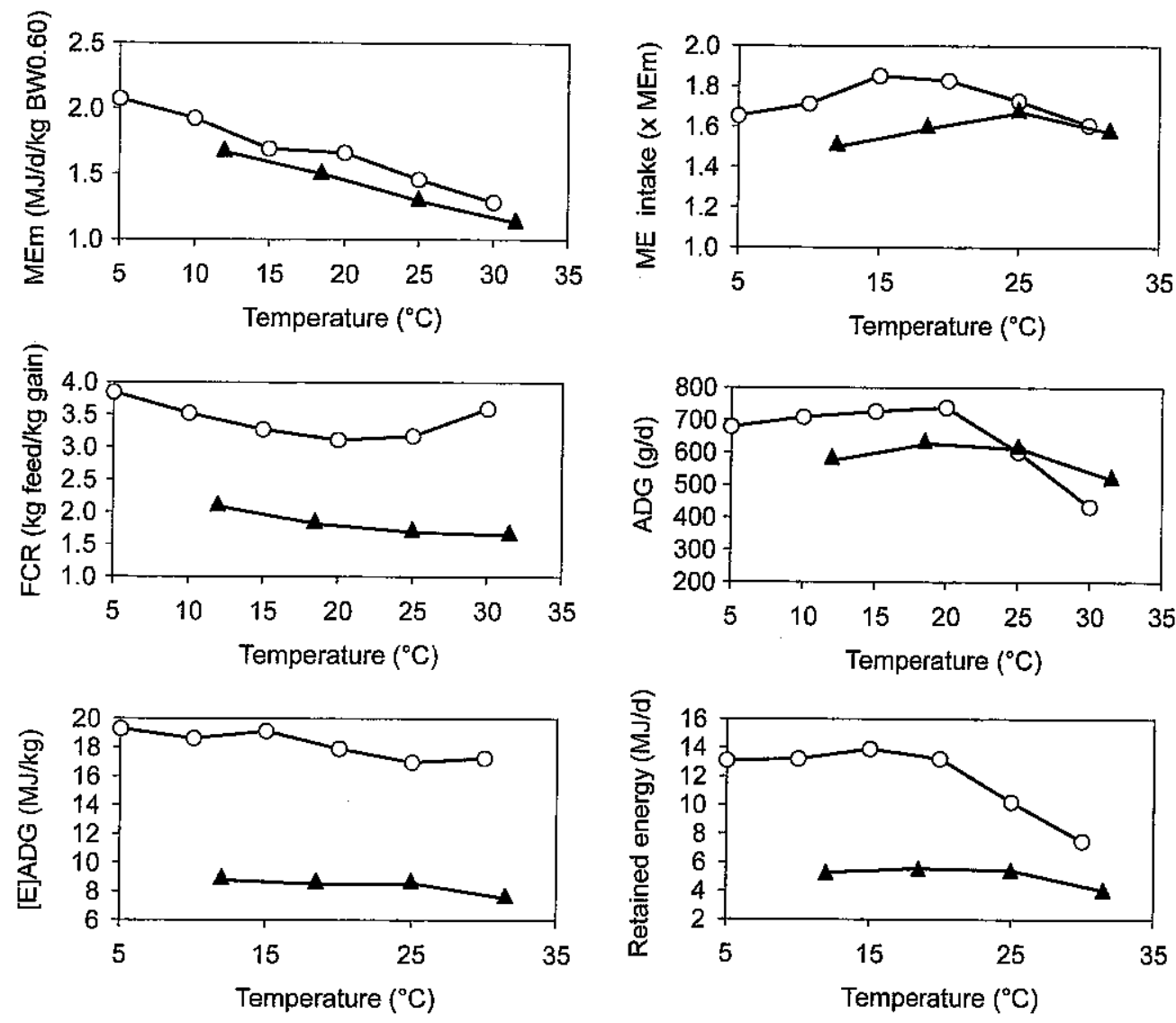

Figure 6. Effect of Ta on energy intake (ME $\times M E m)$, feed conversion ratio (FCR, $\mathrm{kg}$ feed $/ \mathrm{kg}$ gain) and average daily gain ( $A D G, g / d)$ in $20 \mathrm{~kg}$-pigs pig (A) and in $65 \mathrm{~kg}$-pigs (O) (Nienaber et al., 1987; Rinaldo and Dividich, 1991). 
pigs between 20 and $5{ }^{\circ} \mathrm{C}$ (Nienaber and Hahn, 1987) in relation with an increase of carcass fatness (Figure 6). Whatever the physiological stage, the reduction of FCR at low Ta is mainly the consequence of a reduction of the feeding level, expressed as a multiple of MEm and the use of a fraction of the energy intake for thermoregulation. The effect of the feeding level on FCR may be emphasized by the increase of $[\mathrm{E}]_{\text {gain }}$ especially in heavier animals.

At a Ta higher than the optimal range, ADG decreases primarily as a result of a severe decline in feed intake. The increase of FCR in hot conditions (Ta $>24$ to $25^{\circ} \mathrm{C}$ ) depends on both the Ta level and the pig BW (Figures 5 and 6). From 24 to $32^{\circ} \mathrm{C}$, the rates of increase in FCR average 0.020 and $0.035 /{ }^{\circ} \mathrm{C}$ in 25 and $75 \mathrm{~kg} \mathrm{BW}$ pigs, respectively (Figure 5). This increase is not linear and is significant only for extreme $\mathrm{Ta}\left(>30^{\circ} \mathrm{C}\right)$. This increased FCR reflects a reduced proportion of $\mathrm{ME}$ intake available for tissue growth, which is mainly explained by the strong reduction of ME intake rather than an increase in MEm which is not markedly changed. In fact, the slight decrease of MEm at high Ta is more a consequence of the reduced feed intake (Koong et al., 1985; De Lange et al., 2002; Labussière et al., 2011) than a direct effect of the high Ta. Under ad libitum feeding, elevated Ta does not markedly reduce body fatness and $[E]_{\text {gain }}$ (as feed restriction will do at normal Ta) which emphasizes the negative effect of high Ta on FCR.

\section{Pregnant sows}

There is no evidence that cold conditions impair the normal course of pregnancy in the sow. However, pregnant sows are often exposed to a Ta lower than their LCT which can compromise the building of body reserves, unless feeding level is increased. From a compilation of literature, Noblet et al. (1997) showed that the daily increment of heat production with Ta reduction varies with many factors (housing conditions, floor type, feeding level, etc). These latter authors reported that the daily heat increment ranges from 2 to $2.5 \mathrm{kcal} /{ }^{\circ} \mathrm{C} \cdot \mathrm{kg} \mathrm{BW}^{-0.75}$ in group housed sows or in sows close to the LCT or at high feeding levels to 3.6 to $4.3 \mathrm{kcal} /{ }^{\circ} \mathrm{C} \cdot \mathrm{kg} \mathrm{BW}-0.75$ in individuallyhoused sows or at low Ta. For the latter case, it can then be calculated that the amount of feed required to compensate for the increase in heat production is about 60 to $80 \mathrm{~g} / \mathrm{d} /{ }^{\circ} \mathrm{C}$ for a $220 \mathrm{~kg}$ BW sow fed a standard diet.

In pigs, a certain degree of seasonality of reproduction has been reported in many countries. Major manifestations of seasonal infertility in sows include delayed onset of puberty, a prolonged weaning to estrus interval and a reduced proportion of mated sows that farrow. Numerous studies have highlighted the multi-factorial nature of seasonal infertility problem in sows. They are partly explained by reduced semen quality of the boar (Wettmann et al., 1976; Suriyasomboon et al., 2004). However, changes in the photoperiod and/or thermal challenges occurring during the mating period or in the early gestation period (Edwards et al., 1968) or the extent to which maternal body reserves are mobilized during the preceding lactation period (Prunier et al., 2003) also affect reproductive performance. Logically, summer infertility and the related increase in the number of non-productive days have a direct negative consequence on the amount of feed given to pregnant sows per born piglets. In addition, severe heat stress may also result in significant embryo (Wildt et al., 1975) and fetal mortality (Omtvedt et al., 1971), and may emphasize the deterioration of feed efficiency in pregnant sows during the hottest periods of the year. 


\section{Effect of climatic environment on feed efficiency in swine}

\section{Lactating sows}

According to its low LCT $\left(15\right.$ to $18^{\circ} \mathrm{C}$ ), cold is not a problem for lactating sows. In contrast, high Ta is much more problematic for lactating sows which have a high metabolic rate related to milk production. The reduction in HP under hot conditions is mainly achieved by a decrease in feed intake. The average rate of $\mathrm{ME}$ reduction is $645 \mathrm{kcal} / \mathrm{d} /{ }^{\circ} \mathrm{C}$ (Figure 7). However, as shown for growing pigs, the effect of heat stress on feed consumption becomes more pronounced as the Ta increases (Quiniou and Noblet, 1999). Concomitantly, the amount of nutrients and energy available for milk synthesis is reduced with a negative consequence on the litter growth rate $\left(-50 \mathrm{~g} / \mathrm{d} /{ }^{\circ} \mathrm{C}\right.$ on average; Figure 7$)$ and the litter $\mathrm{BW}$ at weaning. In thermoneutral Ta, the energy requirement for milk production generally exceeds feed intake capacity, especially in modern hyper prolific sows. Consequently, the mobilization of body reserves is inevitable to compensate for the energy deficit. On average, the marginal rate of rise in maternal BW loss is $0.046 \mathrm{~kg} /{ }^{\circ} \mathrm{C}$ (Figure 7). Sows losing excessive amounts of body weight have a prolonged weaning to estrus intervals. Under thermal stress, the energy deficit and occurrence of reproductive failure are accentuated, especially in young sows (Prunier et al., 1996). Variation in milk production in hot conditions is mainly explained by reduced feed consumption. However, direct effects of heat stress on milk production and on the mobilization of body reserves have also been reported in primiparous (Messias de Bragança et al., 1998) and multiparous sows (Renaudeau et al., 2003a).

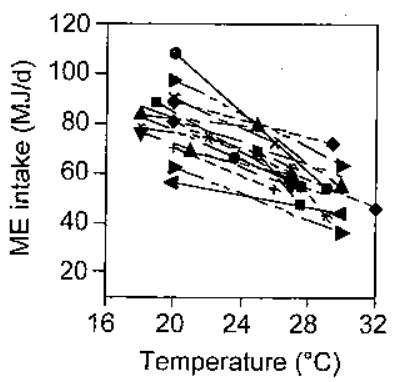

$c$

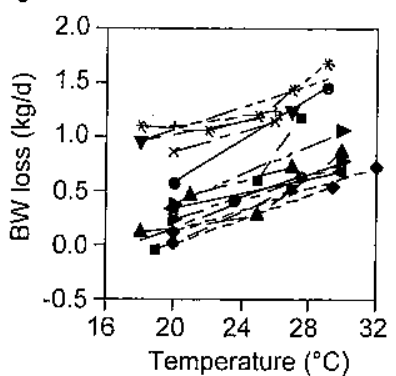

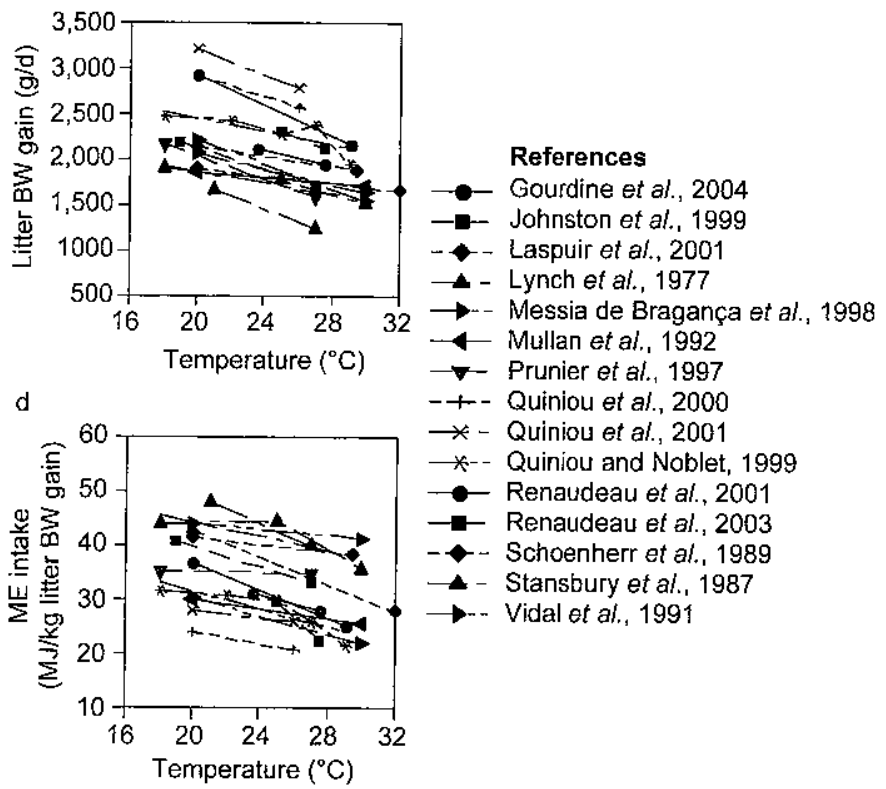

Figure 7. Compilation of the literature data on the effects of elevated ambient temperature on sow performance during lactation: (a) metabolizable energy intake (MJ/d), (b) litter body weight ( $g / d)$, (c) body weight loss ( $\mathrm{kg} / \mathrm{d}$ ), and (d) metabolizable energy intake (MJ/kg litter BW gain) (adapted from Renaudeau, 2008). 


\section{Renaudeau, H. Gilbert, and J. Noblet}

Total feed efficiency for milk production, defined as the ME requirement per unit of litter BW gain, declines when Ta increases (Figure 7). This reduction of the apparent efficiency of ME utilization for milk production could be explained to some extent by an increase in the relative importance of MEm requirement compared to the total ME intake in hot conditions. In addition, heat stress during lactation may also decrease feed efficiency in pregnant sows by increasing the weaning to oestrus interval and/or in the growing-finishing phase by decreasing piglet BW at weaning.

\section{Strategies for alleviating the effects of thermal stress on feed efficiency}

In cold or hot conditions, solutions for improving feed efficiency can be classified into three groups; those promoting a higher energy intake, those decreasing the maintenance requirement and especially extra energy requirement for thermoregulation, and those decreasing the direct effect of thermal stress on pig metabolism, physiology, and health.

\section{Changes in diet composition}

Some evidence shows an interaction between dietary energy content and $\mathrm{Ta}$ on pig metabolism and performance. In growing pigs, TEF is higher in high fiber diets as compared to high starch diets in thermoneutral conditions, whereas, it is similar for both diets in cold conditions (Noblet et al., 1985). Similar results are reported in pregnant sows (Noblet et al., 1989). From these results, the efficiency of ME for energy retention is independent of Ta level for high energy diets but it increases at low Ta for low energy density diets. In fact, TEF of high fiber diets is partly used to meet the pig's elevated maintenance needs in cold whereas it is likely lost or wasted in pigs housed in Ta higher than LCT. In other words, high heat increment diets could be useful in cold conditions because HP related to feed utilization can minimize the amount of the other nutrients or tissues that must be used for extra thermoregulatory HP. Quite logically, in a cold environment, FCR is similar in growing finishing pigs fed high fiber diets compared to those fed high energy corn-soybean meal diets (Coffey et al., 1982). On the other hand, the introduction of fiber rich ingredients in diets has negative consequences on FCR and growth rate under warm conditions.

Pregnant sows are more frequently exposed to cold stress than growing pigs, especially when they are individually housed. The contribution of dietary fiber to net supply of energy is much greater in breeding sows than in growing pigs in connection with a higher ability to digest it (Noblet and Le Goff, 2001) and the energy value of fiber rich ingredients is higher at low Ta (Noblet $e t$ al., 1989). These results are clearly in favor of the use of and the economic interest in high fiber ingredients in pregnant sows exposed to cold conditions.

Few studies have been done to test the effect of high fiber diets on lactating sows in hot conditions. According to Schoenherr et al. (1989), the inclusion of $48 \%$ of wheat bran in lactation aggravates the effect of thermal heat stress on sow performance. In this study, the efficiency of utilization of $\mathrm{ME}$ intake for milk production at $32{ }^{\circ} \mathrm{C}$ was reduced in the high fiber diet in comparison with the basal corn-soybean meal diet ( $8.0 \mathrm{vs.} 6.6 \mathrm{Mcal} \mathrm{ME} / \mathrm{kg}$ litter BW gain). In contrast, in tropicalhumid conditions $\left(26.3{ }^{\circ} \mathrm{C}\right.$ and $89 \% \mathrm{RH}$ on average), we showed that a high fiber diet ( $36 \%$ wheat bran) improved the sow's milk production but had negative effects on the mobilization of maternal body reserves (Renaudeau et al., 2003b). 


\section{Effect of climatic environment on feed efficiency in swine}

In contrast to high fiber diets, low heat increment diets in hot conditions can reduce the amount of HP to be dissipated, increase the portion of energy available for tissue synthesis and global feed efficiency. Some trials were carried out to evaluate the performance of growing-finishing pigs reared under low or high Ta conditions and fed high fat diets. In these studies, the economic value of dietary fat was not only estimated from the impact on fat addition on the amount of feed required per unit of gain, but also on the days required to reach market weight and the pig's carcass merit (fat and lean content). It has been demonstrated that the effects of dietary energy density on FCR depends on the Ta level and to a lesser extent on the BW. In cold conditions, each extra $100 \mathrm{kcal}$ increase in dietary ME content results in a decline of FCR of about $0.10 \mathrm{~kg} \mathrm{feed} / \mathrm{kg}$ gain whereas it remains constant when expressed as Mcal ME intake/kg gain (10.5 Mcal ME $/ \mathrm{kg}$ gain on average; Coffey et al, 1982; Stahly and Cromwell, 1979). In these studies, pigs tended to adjust their voluntary feed intake to the diet energy density for maintaining a constant level of ME intake and then were not markedly improved which can practically limit the economic interest of fat supplementation in cold conditions. In hot conditions, the response of FCR to dietary fat supplementation in growing-finishing pigs is rather similar to that in cold conditions (-0.12/100 Kcal ME on average; Stahly and Cromwell, 1979; Stahly et al., 1981; Katsumata et al., 1996; Spencer et al., 2001). However, dietary fat supplementation at high Ta improved growth performance in growing and in finishing pigs. In hot conditions, high energy diets are better tolerated because these (1) are associated with a reduced TEF, which must be dissipated to the environment and (2) they result in higher energy intake (especially in finishing pigs), which counterbalances to some extent the reduction in feed intake occurring in warm conditions. At thermoneutrality or at high Ta, pigs fed high fat diets are generally fatter than pigs fed control diets and this effect depends on the level of fat supplementation (Stahly and Cromwell, 1979; Stahly et al., 1981; Katsumata et al., 1996; Spencer et al., 2001). This high adiposity is mainly related to an excess of energy relative to protein intake. However, body fat deposition is more strongly affected by level of ME intake at high Ta than at thermoneutrality (Katsumata et al., 1996). This result is partly explained by the large increase in ME intake at elevated Ta. However, using a pair-feeding experimental design, Le Bellego et al. (2001) demonstrated that maximal protein deposition rate can be limited by a direct effect of high $\mathrm{Ta}$ and they suggested that the increase in energy intake in hot conditions by dietary manipulations benefits mainly or more to the lipid than to the protein deposition and increases carcass fatness.

The response to high dietary fat addition- diets has also been studied in heat stressed lactating sows but to a lesser extent. When high-fat diets were used without an increase in CP or essential amino acids (AA) to maintain a constant protein/ME ratio, the BW loss during lactation and the milk yield were not affected by the dietary treatment (McGlone et al., 1988). In contrast, when the diet was correctly balanced for protein or lysine to $\mathrm{ME}$ ratio, the increase in diet nutrient density in heat stressed sows improved litter BW gain, via an increase in milk-fat content, but it did not limit the mobilization of body reserves (Dove and Haydon, 1994; Quiniou et al., 2000b; Schoenherr et al., 1989). However, the magnitude of these effects seems to be dependent on the rate of dietary fat in the diet.

The utilization of low heat increment diets based on a reduction of dietary crude protein level has been tested both in growing pigs and in lactating sows in order to attenuate the effect of high Ta on voluntary feed intake and performance. As reviewed by Renaudeau et al. (2008), the 


\section{Renaudeau, H. Gilbert, and J. Noblet}

utilization of low CP diets at high ambient temperature moderately improves energy intake in hot conditions; the effect seems to be significant only in finishing pigs (Spencer et al., 2001). In lactating sows, the results show great variability. In response to a reduced protein level from 16.8 to $14.3 \%$, Quiniou and Noblet (1999) did not report any improvement in performance of lactating sows housed at $29^{\circ} \mathrm{C}$. Johnston et al. (1999) observed an increase in litter BW gain ( $\left.+60 \mathrm{~g} / \mathrm{d}\right)$ in the hot season for mixed parity sows fed a low CP diet (13.7 vs. 16.5\%). In this study, the increase in daily weight gain of the litter was attributed to an increase in the mobilization of sow body reserves due to a probable imbalance of some essential AA (threonine, tryptophan, and valine) in the LP diet. In experiments in which essential AA supplies were kept constant and adequately balanced, heat stressed sows fed low CP diets tended to consume more energy and mobilize fewer body reserves (Renaudeauet al., 2001; Silva et al., 2009a).

\section{Other feeding strategies}

With respect to the postnatal management of the piglet, provision of an early intake of colostrum or milk replacer for all the piglets or only to the weak, light, and latter born piglets could be useful to promote survival especially at low Ta. A variety of energy compounds including glucose, lactose, and lipids have been tested as energy supplements for neonatal pigs with little success (Noblet et al., 2001). For example, providing supplemental energy as oral doses of corn oil during the $48 \mathrm{~h}$ post partum did not significantly improve pre-weaning mortality (Pettigrew et al., 1986).

The growth of nursing piglets is directly dependent on the ability of the sow to produce milk. As mentioned above, milk yield is reduced in heat stressed sows which lowers the litter BW gain. To supplement milk production, producers can provide piglets with creep feed or starter diets based predominately on cereals and various sources of animal proteins. At thermoneutrality, creep feed intake is generally low and highly variable among the litters within each study and between each study (see review of Pluske et al., 1995). When offered during the last week of lactation, the amount of creep feed consumed before weaning by nursing piglets was higher when sows were kept in hot conditions (Renaudeau and Noblet, 2001). This higher intake was interpreted as an adaptation to compensate for insufficient milk production by the heat-stressed sows. Moreover, Azain et al. (1996) showed that providing litters with a milk substitute during the warm season is more effective in improving litter BW gain than during the cool season $(+38$ vs. $+10 \%)$. In addition, it has been shown that supplying milk replacer to piglets during periods of heat stress could attenuate the maternal BW loss and improve post-weaning reproductive performance (Spencer et al., 2003). These results suggest that the provisioning of supplemental feed or milk substitutes can attenuate the reduced growth rate of nursing piglets during heat stress and have a subsequent positive effect on post weaning growth performance. However, these practices need to be economically evaluated in regard to the high cost of these types of substitutes.

Water is an essential nutrient for livestock, especially during a thermal stress. Water intake during heat stress is a limiting factor for survival and performance since water has a fundamental role in the heat exchange system required for temperature regulation and maintenance of water balance (Mroz et al., 1995). Whatever the physiological stage, water restriction enhances the negative effect of thermal stress on animal performance and especially on FCR (Nienaber and Hahn, 1984; Leibbrandt et al., 2001). In hot conditions, water losses increase (evaporation by panting) 


\section{Effect of climatic environment on feed efficiency in swine}

and water ingested in feed and generated by metabolism is reduced. Consequently, drinking water consumption has to increase to meet the requirements of a heat-stressed animal. In warm climates, a key husbandry practice is to provide an abundant clean source of drinking water close to the feeding area. Moreover, in many high temperature regions, drinking water provided to pigs is often warm. Some studies demonstrated that providing chilled water would improve animal performance by reducing body temperature through absorbed heat energy (West, 2003; Jeon et al., 2006). However, it must be considered that most animals are limited in chilled water consumption. According to Jeon et al. (2006), chilled water $\left(22\right.$ to $\left.15^{\circ} \mathrm{C}\right)$ can provide sufficient cooling to allow lactating sows to increase their feed intake $(+40 \%)$ and milk production $(+20 \%)$ during heat stress.

\section{Environmental modifications}

A broad spectrum of environmental and technical solutions can be used to temper the effects of high or low Ta on feed efficiency in pigs. Whatever the climate, in order to reduce the effect of Ta on FCR, approaches leading to reduce the extra energy expenses for thermoregulation and/ or to increase energy intake must be favoured. Classically, these approaches can be divided in two groups, those modifying the climatic environment to prevent or limit the degree of heat/cold stress to which the animals are exposed or those enhancing/decreasing heat exchanges between the animal and the environment (Renaudeau et al., 2011a). Basically, the decision on the degree to modify the animal environment depends upon the cost of providing improved performance compared with the value of improved performance. In other words, the merit of maximizing feed efficiency from an environment standpoint may be questionable according to the relative price of feed versus energy.

Maintaining the Ta at or higher than the LCT during the 7 to $14 \mathrm{~d}$ period following weaning helps to avoid loss of excessive body fat and hence limits the reduction of thermal insulation and cold stress and associated consequences of weaning on health (diarrhoea) and on performance (post weaning growth lag) (Le Dividich et al., 1998). Thereafter, once regular feed intake is established, Ta can be reduced by about 2 to $3^{\circ} \mathrm{C}$ until the Ta to be maintained in the finishing house is reached (Noblet et al., 2001). During this period, a moderate reduction of Ta does not have marked detrimental effects on growth performance because the pig is generally able to compensate for the extra energy requirement for thermoregulation by increasing its voluntary feed intake (Rinaldo and Dividich, 1991). The related increase in FCR and the associated economic loss can be avoided by maintaining the post weaning house at an optimal Ta. In practice, especially during the winter season in temperate climates, a high amount of heating in weaning houses is required to maintain Ta within the thermoneutral zone and the cost of providing this improved environment has to be considered. Several ways of reducing the heating requirement while maintaining piglet performance at acceptable levels have been investigated. As reviewed by Le Dividich and Herpin (1994), these solutions include the provision of a microenvironment and/or the reduction in nocturnal temperature. The creation of a microenvironment within the post-weaning crate is considered the simplest way to save heating costs. For example, hovers and covers are effective devices to reduce draughts and to capture heat generated by the piglets. According to Shelton and Brumm (1984), pigs subjected to these energy management techniques generally performed similar to, or better than, pig housed at recommended air temperatures. The reduction in 


\section{Renaudeau, H. Gilbert, and J. Noblet}

nocturnal temperature is based on the fact that the pig displayed marked circadian variation in its metabolic rate; its LCT is lower during the night time than during the daytime (Van Der Hel et al., 1984). Compared with a constant $\mathrm{Ta}$, a 4 to $10^{\circ} \mathrm{C}$ reduction in nocturnal Ta did not affect pig performance but it decreased heating costs by 16 to $35 \%$ (Brumm et al., 1985; Brumm and Shelton, 1988; Brumm and Shelton, 1991; Nienaber and Hahn, 1989). However, pigs on the reduced nocturnal treatment where the reduction in Ta was higher than $8^{\circ} \mathrm{C}$ tended to have a higher incidence and severity of scouring. In some cases, the reduced nocturnal temperature can deteriorate FCR due to an increase in feed intake, especially during the night (Rinaldo, 1989).

When compared with post weaning pigs, growing-finishing pigs allowed ad libitum access to feed are less sensitive to cold Ta. Once the other climatic parameters (draughts, relative humidity) are controlled, the effect of Ta on FCR can be alleviated by providing supplemental heat to the building. However, this can be costly and is not practical in cases using lower-cost open-front housing systems. In this situation, providing wind protection for the pigs on three sides and dry bedding (straw, wood shavings, or other similar materials) in the sleeping area are adequate to prevent cold stress.

From an economical point of view, heat stress is a greater problem for growing-finishing pigs than is cold stress because of its negative effects on both FCR and growth rate. As the group size can influence critical temperatures (Close and Clark, 1981), the number of pigs per pen should be reduced with the aim to increase the minimum floor space allowed to the pigs. One of the most effective methods to promote heat losses under high Ta involves the addition of water to the skin with or without supplemental air flow to increase the rate of evaporation of the additional water. Water evaporation occurs by absorbing heat directly from the body of the animal and also by absorbing water to the surrounding air. The efficiency of these systems depends on the magnitude of thermal stress, the pig BW and the conditions of the water application (Renaudeau et al., 2011a). The interval between wettings, the duration of water application, and the amount of supplied water per wetting need to be considered to maximize evaporative heat losses. With sprinklers operating intermittently ( $1 \mathrm{~min}$ on and $14 \mathrm{~min}$ off) below $29.5^{\circ} \mathrm{C}$ and continuously above $29.5^{\circ} \mathrm{C}$, feed intake and average daily gain were improved by $13 \%$ in heat stressed finishing pigs (Nichols et al., 1987). In that study, the reduction of water flow rate from 1.6 to $0.81 / \mathrm{pig} / \mathrm{h} \mathrm{did}$ not change the performance of the spray cooling system. The advantage of wetting finishing pigs during heat stress is supported by the results presented in Table 2. Whatever the wetting system, the growth performance was improved when compared to the control group. The experiment shows that the intermittent wetting system is more effective than continuous fogging system and the effect of intermittent sprinkling on voluntary feed intake were large enough to improve FCR. In fact, for evaporative cooling to be valuable, water must be applied intermittently to permit time for evaporation of the moisture at the skin surface. This rate of evaporation can be improved by providing supplemental air flow (Turner et al., 1997).

As described before, the thermal requirement of lactating sows differs from that of suckling piglets. In practice, Ta in the farrowing barn is kept at a compromise between the requirement of the sow and the piglets. This means that Ta is too low for the litter, especially during the first days following the farrowing, and too high for the sows. This thermal dilemma is accentuated either in cold or in heat stress situations. For avoiding this problem, two microclimates have 


\section{Effect of climatic environment on feed efficiency in swine}

Table 2. Effects of the cooling system on growth performance in finishing pigs (initial $B W=51 \mathrm{~kg}$ ) during summer (adapted from Nichols et al., 1979).

\begin{tabular}{lccc} 
& Cooling system & & \\
& Control & Fogger & Sprinkler $^{2}$ \\
& & & \\
No. of pigs & 40 & 40 & 40 \\
Feed intake $(\mathrm{kg} / \mathrm{d})$ & 1.95 & 2.21 & 2.36 \\
Average daily gain $(\mathrm{kg} / \mathrm{d})$ & 0.521 & 0.580 & 0.698 \\
FCR $(\mathrm{kg} / \mathrm{kg})^{3}$ & 3.75 & 3.84 & 3.39 \\
\hline
\end{tabular}

1 System that generated low volume, small droplet nozzles and operated continuously when Ta exceeded $26.7^{\circ} \mathrm{C}$.

${ }^{2}$ System that generated high volume, large droplet nozzles and operated intermittently ( 1 min on followed by 29 min off) when Ta exceeded $26.7^{\circ} \mathrm{C}$

${ }^{3} \mathrm{FRC}=$ feed conversion ratio.

to be used to cool the sows without detrimental effects on piglet's well-being and/or to warm piglets without causing heat stress in sows. An infrared lamp located over the creep area and/or a heated floor are the most common methods used to provide a thermal environment suitable for the newborn piglet (Kuhn, 1990). However, the provision of an adequate environment must take into account the behaviour of the newborn piglet. During the first days of life, the newborn prefers to lie close to the sow udder rather than in the heat area which increases the risk of being crushed by the sow (Hrupka et al., 1998). To avoid this problem, a movable infrared lamp is placed at the rear of the sow during parturition to avoid excessive changes in the piglet's body temperature. Thereafter, the lamp is used to direct the piglet away from the zone of the sow and attract them progressively towards the heating device (heating lamp or map) in the creep area. Covering the creep area was found to be effective in reducing heat losses in piglets. Because of the high susceptibly of the lactating sows to high $\mathrm{Ta}$, a lot of alternatives were tested in order to increase heat exchange between the animal and the environment. Provision of supplemental fresh air directly on the sow's head and neck ('snout cooler') was found to be an efficient way to improve performance under heat stress. At $30^{\circ} \mathrm{C}$, the average daily feed intake was increased by 25 to $35 \%$ when snout coolers were used to cool the sow (McGlone et al., 1988; Stansbury et al., 1987). In these latter studies, voluntary feed intake and milk production were also increased by $24 \%$ and $19 \%$ by using a drip cooling method based on the application of a water drip for 3 min every $10 \mathrm{~min}$. As previously described, the reduction of energy intake in heat stressed animals is mainly related to the inability to dissipate sufficient body heat to the environment. As the lactating sow spends about 85 to $90 \%$ of the day resting (Renaudeau $e t$ al., 2002), most of the time a large part of its body is in contact with the floor. Thus, cooling the floor under the sow in the farrowing crate should increase the dissipation of sow's body heat by conduction (Table 3). It is interesting to note that the benefit of a floor cooling system for milk production seems to be higher than for feed intake. This result also confirms the direct effect of high Ta on mammary gland metabolism. Finally, use of the floor cooling system did not reduce piglet mortality; it has been suggested that the surface temperature was not low enough to keep the piglet away (Wagenberg et al., 2006). 


\section{Renaudeau, H. Gilbert, and J. Noblet}

Table 3. Effect of floor cooling system on performance of lactating sows and their litter?.

\begin{tabular}{|c|c|c|c|c|c|c|}
\hline Reference & Treatment & No. of sows & $A D F I(k g / d)$ & BW loss $(\mathrm{g} / \mathrm{d})$ & $\operatorname{LBWg}(\mathrm{kg} / \mathrm{d})$ & WEI (d) \\
\hline \multirow[t]{2}{*}{ Wagenberg et al. $(2006)^{2}$} & control & 29 & 4.90 & 1,060 & 2.52 & - \\
\hline & $\mathrm{cool}$ & 29 & 5.50 & 943 & 2.93 & - \\
\hline \multirow[t]{2}{*}{ Silva et al. $(2006)^{3}$} & control & 20 & 5.60 & 276 & 1.70 & 4.3 \\
\hline & cool & 20 & 6.47 & -133 & 2.17 & 3.9 \\
\hline \multirow[t]{2}{*}{ Silva et al. $(2009 b)^{4}$} & control & 14 & 4.71 & 580 & 1.96 & 5.7 \\
\hline & cool & 15 & 5.48 & 328 & 2.57 & 4.0 \\
\hline
\end{tabular}

${ }^{1} \mathrm{Abbreviations} \mathrm{used:ADFI}=$ average daily feed intake; $B$ W loss = maternal $B W$ loss during the whole lactation period; $\mathrm{LBWg}=$ litter $\mathrm{BW}$ gain during lactation; $\mathrm{WE}=$ = weaning to estrus interval.

${ }^{2}$ Study performed in Netherlands with an average Ta on $24^{\circ} \mathrm{C}$

${ }^{3}$ Study performed in Brazil with an average Ta on $23.5^{\circ} \mathrm{C}$

${ }^{4} \mathrm{Study}$ performed in Brazil with an average $\mathrm{Ta}$ on $25.5^{\circ} \mathrm{C}$

\section{Genetic strategies}

Whatever the physiological stage, the depressed effect of thermal stress on FCR cannot be totally eliminated by management solutions. Moreover, most of these practices are not economically or technically feasible in all livestock production systems. As a consequence, selection for pigs able to maintain a low FCR whatever the Ta, if successful, could be the most cost-effective method for mitigating the effects of thermal stress on FCR.

In growing pigs, an important part (60-70\%) of voluntary feed consumption can be explained by maintenance and production requirements (Dekkers and Gilbert, 2010). The remaining variation, referred to as residual feed consumption (RFC), may be used for direct selection of feed efficiency without any change in production. In practice, RFC of individual growing pigs can be estimated as the residual of a multiple linear regression for feed intake that includes growth rate and body composition (backfat thickness or carcass lean content) as covariates to account for production requirements, along with metabolic $\mathrm{BW}$ to account for maintenance requirements (Mrode and Kennedy, 1993). As far as we know, only two selection experiments for RFC have been conducted in growing pigs, one at INRA (Gilbert et al., 2007) and the other one at Iowa State University (Cai et al., 2008), both in purebred Large White/Yorkshire pigs. Details on the selections designs have been given by Gilbert et al. (2007) and Cai et al. (2008). The selection on RFC has shown to be effective in creating lines of pigs having different feed intake levels but a rather similar growth potential. Among others, individual variations in RFC can reflect differences in digestion and/ or metabolic utilization of feed which includes differences in heat production and/or in body composition. From a comparison of two divergent lines with a low (RFC-) or a high RFC (RFC+) over 4 generations of selection from the INRA experiment, it has been shown that digestibility of a conventional cereals-soybean meal-diet did not differ between the two lines (Barea et al., 2010). However, the efficiency of ME utilization for growth was higher in RFC- than in RFC+ pigs, in connection to a reduced total $\mathrm{HP}$ ( $9 \%$ reduction in $\mathrm{RFC}$ - pigs compared to $\mathrm{RFC}+$ pigs; 


\section{Effect of climatic environment on feed efficiency in swine}

Table 4). This difference is mainly due to a reduced basal metabolic rate and, to a lesser extent, lower physical activity (9\% reduction in RFC- pigs; Table 4). According to the importance of HP on thermoregulatory responses, selection for RFC is assumed to be able to change the ability of the pig to cope with thermal stress. We have tested this hypothesis through two experiments conducted at INRA by exposing pigs to a thermal heat stress in which they were exposed to $24^{\circ} \mathrm{C}$ (thermoneutrality) during one week and, thereafter, to a constant high $\mathrm{Ta}\left(30\right.$ or $\left.32{ }^{\circ} \mathrm{C}\right)$ for 2 or 3 weeks. A first experiment was designed to determine the effect of selection for RFC on energy utilization during a thermal heat acclimation period, in pigs individually housed in respiration chambers for a $28 \mathrm{~d}$ period. As expected, feed intake and total HP were significantly reduced under thermal stress (Figure 8 ). However, these changes were not significantly affected by line. From data obtained in a second experiment on a larger number of pigs, we found that pigs with a low RFC tended to have a greater ADG $(+50 \mathrm{~g} / \mathrm{d})$ and a lower FCR $(-0.40)$ at $30^{\circ} \mathrm{C}$ when compared to pig with a high RFC (Figure 9). These preliminary results would suggest that the selection for RFC could improve the capacity of pigs to cope with heat stress. However, further studies are required to validate these results in growing pigs under practical conditions such as those encountered in tropical areas, and to identify the correlated effects of selection for FCR on the ability of other physiological stages (piglets, lactating sows) to tolerate cold or hot conditions.

\section{Conclusion}

Thermal stress negatively impacts the global feed efficiency on a pig farm by changing the energy intake and the metabolic utilization of energy for tissue deposition, by reducing the overall productivity of sows, and/or by increasing the mortality rate whatever the physiological stages. This lower feed efficiency, when combined with other direct and indirect losses of production related to climate effects, results in very important economic impacts on the pig industry. Current and past research has resulted in significant improvements in pig management in cold and hot conditions. This chapter provides a non exhaustive review of the strategies available to alleviate

Table 4. Effect of a divergent selection for the residual feed consumption (RFC) on energy balance ( $\mathrm{kcal} \cdot \mathrm{kg}$ of $B W^{0.60} /$ d) in growing pigs (adapted from Barea et al. 2010).

\begin{tabular}{lll} 
& RFC+ & RFC - \\
No. of pigs & 12 & 12 \\
Average BW $(\mathrm{kg})$ & 60.4 & 60.0 \\
ME intake & $668^{\mathrm{a}}$ & $622^{\mathrm{b}}$ \\
Heat production $(\mathrm{HP})$ & & \\
$\quad$ Fasting HP & $202^{\mathrm{a}}$ & $184^{\mathrm{b}}$ \\
$\quad$ Activity HP & $60^{\mathrm{a}}$ & $52^{\mathrm{b}}$ \\
$\quad$ TEF $^{1}$ & 94 & 93 \\
Total & $352^{\mathrm{a}}$ & $332^{\mathrm{b}}$ \\
\hline
\end{tabular}

${ }^{a, b}$ Rows with diferent superscript are significantly differerent $(P<0.05)$.

${ }^{1} \mathrm{TEF}=$ thermic effect of feeding. 


\section{Renaudeau, H. Gilbert, and J. Noblet}

a

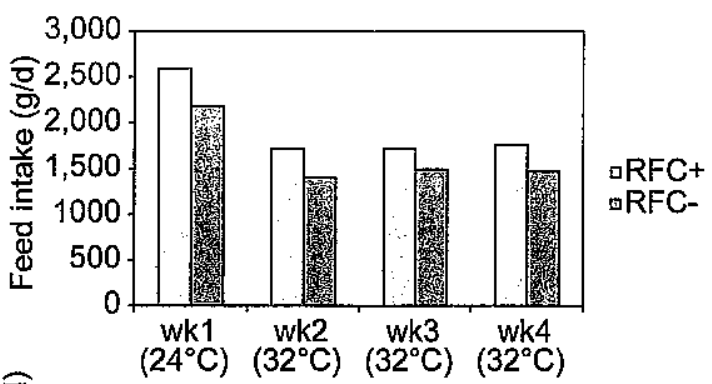

b

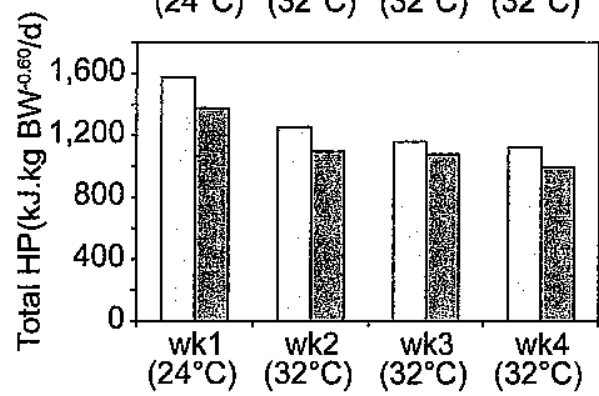

aRFC+

Figure 8. Effects of the line and the duration of exposure to $32{ }^{\circ} \mathrm{C}$ on (a) feed intake and (b) total heat production (HP) in growing pigs. Pigs (5/ine) were kept at $24^{\circ} \mathrm{C}$ for 7 days and thereafter at $32^{\circ} \mathrm{C}$ for 21 days (Renaudeau, Frances, Dubois, Gilbert, Noblet, unpublished results).

a

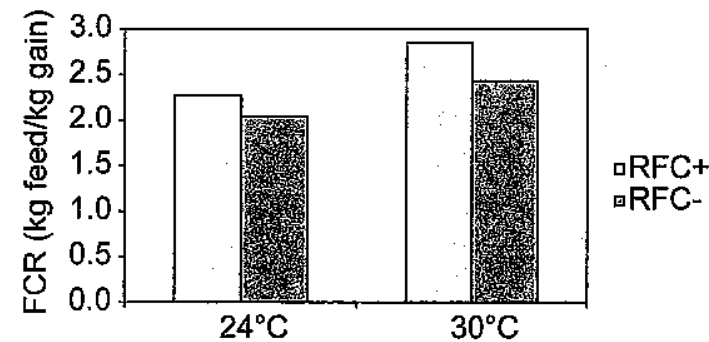

b

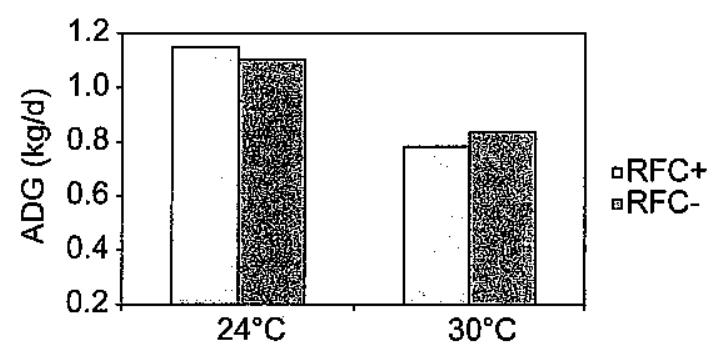

Figure 9. Effect of line and ambient temperature on (a) average daily $B W$ gain (ADG) and (b) feed conversion ratio (FCR) in growing pigs. Pigs (17RFC+ and to 19 RFC-) were kept at $24^{\circ} \mathrm{C}$ for 7 days and thereafter at $30^{\circ} \mathrm{C}$ for 14 days (Campos, Renaudeau, Gilbert, Noblet, unpublished results). 


\section{Effect of climatic environment on feed efficiency in swine}

the effects of Ta changes on feed efficiency and, more generally, on pig performance. Maximizing production levels and the feed efficiency of pig farms is important but economic considerations largely determine the level of environmental or feeding manipulations used to cope with thermal stress. In the future, efforts have to be developed to select animals with high production efficiency and optimal heat tolerance.

\section{References}

Azain, M. J., T. Tomkins, J. S. Sowinski, R. A. Arentson, and D. E. Jewell. 1996. Effect of supplemental pig milk replacer on litter performance: seasonal variation in response. J. Anim. Sci. 74:2195-2202.

Barea, R., Dubois, S., Gilbert, H., Sellier, P., Van Milgen, J., and Noblet, J. 2010. Energy utilization in pigs selected for high and low residual feed intake. J. Anim Sci. 88:2062-2072.

Berthon, D., P. Herpin, and J. l. Dividich. 1994. Shivering thermogenesis in the neonatal pig. J. Therm. Biol. 19:413-418.

Black, J. L., B. P. Mullan, M. L. Lorschy, and L. R. Giles. 1993. Lactation in the sow during heat stress. Livest. Prod. Sci. 35:153-170.

Brown-Brandi, T. M., R. A. Eigenberg, J. A. Nienaber, and S. D. Kachman. 2001. Thermoregulatory profile of a newer genetic line of pig. Livest. Prod. Sci. 71:253-260.

Brumm, M. C., and D. P. Shelton. 1988. A modified reduced nocturnal temperature regimen for earlyweaned pigs. J. Anim. Sci. 66:1067-1072.

Brumm, M. C., and D. P. Shelton. 1991. Two reduced nocturnal temperature regimens for early-weaned pigs. J. Anim. Sci. 69:1379-1388.

Brumm, M. C., D. P. Shelton, and R. K. Johnson. 1985. Reduced nocturnal temperatures for early weaned pigs 1, 2, 3. J. Anim. Sci. 61:552-558.

Cai, W., D. S. Casey, and J. C. M. Dekkers. 2008. Selection response and genetic parameters for residual feed intake in Yorkshire swine. J. Anim. Sci. 86:287-298.

Canario, L., E. Cantoni, E. Le Bihan, J. C. Caritez, Y. Billon, J. P. Bidanel, and J. L. Foulley. 2006. Betweenbreed variability of stillbirth and its relationship with sow and piglet characteristics. J. Anim. Sci. 84:3185-3196.

Close, W. H. 1987. The influence of the thermal environment on the productivity of pigs. BSAP Occasional Publication 11:9-24.

Close, W. H., and J. A. Clark. 1981. The climatic requirements of the pig Environmental aspects of housing for animal production No. Butterworths. p 149-166. Butterworths, London.

Coffey, M. T., R. W. Seerley, D. W. Funderburke, and H. C. McCampbell, 1982. Effect of heat increment and level of dietary energy and environmental temperature on the performance of growing-finishing swine. J. Anim. Sci. 54:95-105.

Comberg, G., E. Stephan, and H. Spath. 1972. The reaction of German Landrace boar progeny groups to different climatic pen conditions. Pt. 3. Zuchtungskunde 44:402-415.

Curtis, S. E. 1983. Environmental management in animal agriculture, Ames/lowa.

De Lange, C. F. M., J. van Milgen, J. Noblet, S. Dubois, and S. H. Birkett. 2002. Previous feeding level influences fasting heat production in growing pigs. J. Anim. Sci. 80 (suppl. 1):63.

Dekkers, J. C. M., and H. Gilbert. 2010. Genetic and biological aspect of residual feed intake in pigs, Leipzig, Germany. p 8 pp.

Dove, C. R., and K. D. Haydon. 1994. The effect of various diet nutrient densities and electrolyte balances on sow and litter performance during two seasons of the year. J. Anim. Sci. 72:1101-1106. 


\section{Renaudeau, H. Gilbert, and J. Noblet}

Edwards, R. L., I. T. Omtvedt, E. J. Turman, D. F. Stephens, and G. W. A. Mahoney. 1968. Reproductive performance of gilts following heat stress prior to breeding and in early gestation. J. Anim. Sci. 27:1634-1637.

Feddes, J. J. R., J. A. DeShazer, and A. M. Parkhurst. 1988. Dynamic responses of growing pigs to high cyclic and constant temperature, St. Joseph, Mich. p 85-92.

Geuyen, T. P. A., J. M. F. Verhagen, and M. W. A. Verstegen. 1984. Effect of housing and temperature on metabolic rate of pregnant sows. Animal Production 38:477-485.

Gilbert, H., J. P. Bidanel, J. Gruand, J. C. Caritez, Y. Billon, P. Guillouet, H. Lagant, J. Noblet, and P. Sellier. 2007. Genetic parameters for residual feed intake in growing pigs, with emphasis on genetic relationships with carcass and meat quality traits. J. Anim Sci. 85:3182-3188.

Henry, Y., and J. Noblet. 1986. Alimentation énergétique Le porc et son élevage. p. 233-260.

Herpin, P., M. Damon, and J. Le Dividich. 2002. Development of thermoregulation and neonatal survival in pigs. Livest. Prod. Sci. 78:25-45.

Herpin, P., J. Le Dividich, J. C. Hulin, M. Fillaut, F. De Marco, and R. Bertin. 1996. Effects of the level of asphyxia during delivery on viability at birth and early postnatal vitality of newborn pigs. J. Anim. Sci. 74:2067-2075.

Holmes, C. W., and W. H. Close. 1977. The influence of climatic variables on energy metabolism and associated aspects of productivity in the pig. p 51-73 in Nutrition and the climatic environment. Studies in the agricultural and food sciences. Butterworths, London, UK.

Hrupka, B. J., V. D. Leibbrandt, T. D. Crenshaw, and N. J. Benevenga. 1998. The effect of farrowing crate heat lamp location on sow and pig patterns of lying and pig survival. J. Anim. Sci. 76:2995-3002.

Huynh, T. T. T., A. J. A. Aarnink, M. W. A. Verstegen, W. J. J. Gerrits, M. J. W. Heetkamp, B. Kemp, and T. T. Canh. 2005. Effects of increasing temperatures on physiological changes in pigs at different relative humidities. J. Anim. Sci. 83:1385-1396.

Ingram, D. L. 1964. The effect of environemental temperature on body temperature, respiratory frequency and pusle rate in the young pig. Research Veterinary Science 5:348-356.

Jeon, J. H., S. C. Yeon, Y. H. Choi, W. Min, S. Kim, P. J. Kim, and H. H. Chang. 2006. Effects of chilled drinking water on the performance of lactating sows and their litters during high ambient temperatures under farm conditions. Livestock Science 105:86-93.

Johnston, L. J., M. Ellis, G. W. Libal, V. B. Mayrose, and W. C. Weldon. 1999. Effect of Room Temperature and Dietary Amino Acid Concentration on Performance of Lactating Sows. J. Anim. Sci. 77:1638-1644.

Kammersgaard, T. S., L. J. Pedersen, and E. Jorgensen. 2011. Hypothermia in neonatal piglets: Interactions and causes of individual differences. J. Anim. Sci. 89:2073-2085.

Katsumata, M., Y. Kaji, and M. Saitoh. 1996. Growth and carcass fatness responses of finishing pigs to dietary fat supplementation at a high ambient temperature. Anim. Sci. 62:591-598.

Kemp, B., M. W. A. Verstegen, L. A. den Hartog, and H. J. G. Grooten. 1989. The effect of environemental temperature on metabolic rate and partitoning of energy intake in breeding boars. Livest. Prod. Sci. 23:329-340.

Koong, L. J., C. Ferrell, and J. A. Nienaber. 1985. Assessment of interrelationships among level of intake and production, organ size and fasting heat production in growing animals. J. Nutr. 115:1383-1390.

Kovacs, F., and P. Rafai. 1973. Metabolism in newborn and young pigsAz ujszulott es fiatal malacok anyagcserejenek vizsgalata. Magy. Allatorv. Lapja 28:182-187.

Kuhn, J. 1990. Klimatisierung von Abferkelstallen. Deutsche Geflugelwirtschaft und Schweineproduktion 28:830-835.

Labussière, E., J. van Milgen, C. F. M. de Lange, and J. Noblet. 2011. Maintenance energy requirements of growing pigs and calves are influenced by feeding level. The Journal of Nutrition 141:1855-1861. 


\section{Effect of climatic environment on feed efficiency in swine}

Le Bellego, L., . van Milgen, and J. Noblet. 2001. Effect of high temperature and energy intake on energy utilization in growing pigs. J. Anim. Sci. 79 (Suppl.1):211.

Le Dividich, J. 1999. A review - Neonatal and weaner pig: management to reduce variation, Adelaide, South Australia. p 135-155.

Le Dividich, J. 2006. The issue of colostrum in piglet survival: energy and immunity. Page 89-102. Nutritional biotechnology in the feed and food industries: Proceedings of Alltech's 22nd Annual Symposium, Lexington, Kentucky, USA, 23-26 April 2006.

Le Dividich, J., and P. Herpin. 1994. Effects of climatic conditions on the performance, metabolism and health status of weaned piglets: a review. Livest. Prod. Sci. 38:79-90.

Le Dividich, J., and J. Noblet. 1981. Colostrum intake and thermoregulation in the neonatal pig in relation to environmental temperature. Neonatology 40:167-174.

Le Dividich, J., J. Noblet, P. Herpin, J. van Milgen, N. Quiniou, J. Wiseman, M. A. Varley, and J. P. Chadwick. 1998. Thermoregulation progress in pig science. p 229-263. Nottingham University Press, Nottingham.

Le Dividich, J., M. Vermorel, J. Noblet, J. C. Bouvier, and A. Aumaitre. 1980. Effects of environmental temperature on heat production, energy retention, protein and fat gain in early weaned piglets. Br. J. Nutr. 44:313-323.

Leibbrandt, V. D., L. J. Johnston, G. C. Shurson, J. D. Crenshaw, G. W. Libal, and R. D. Arthur. 2001. Effect of nipple drinker water flow rate and season on performance of lactating swine. J. Anim. Sci. 79:2770-2775.

McGlone, J. J., W. F. Stansbury, and L. F. Tribble. 1988. Management of lactating sows during heat stress: effects of water drip, snout coolers, floor type and a high energy-density diet. J. Anim. Sci. 66:885-891.

Mellor, D. J., and F. Cockburn. 1986. A comparison of energy metabolism in the new-born infant, piglet and lamb. Exp. Physiol. 71:361-379.

Messias de Bragança, M., A. M. Mounier, and A. Prunier. 1998. Does feed restriction mimic the effects of increased ambient temperature in lactating sows? J. Anim. Sci. 76:2017-2024.

Mount, L. E., J. L. Monteith, and L. E. Mount. 1974. The concept of thermal neutrality Heat loss from animals and man. p 425-439. Butterworths, London.

Mrode, R. A., and B. W. Kennedy. 1993. Genetic variation in measures of food efficiency in pigs and their genetic relationships with growth rate and backfat. Animal Production 56:225-232.

Mroz, Z., A. W. Jongbloed, N. P. Lenis, and K. Vreman. 1995. Water in pig nutrition: physiology, allowances and environmental implications. Nutr. Res. Rev. 8:137-164.

Nichols, D. A., D. R. Ames, and R. H. Hines. 1979. Evaporative cooling systems for swine. Report of Progress, Agricultural Experiment Station, Kansas State University:6-9.

Nichols, D. A., R. C. Thaler, J. P. Murphy, R. H. Hines, and J. L. Nelssen. 1987. The value of drip versus spray cooling at two flow rates to reduce heat stress of finishing pigs. Report of Progress, Agricultural Experiment Station, Kansas State University:58-60.

Nienaber, J. A., and G. L. Hahn. 1983. Performance of growing-finishing swine in response to the thermal environment. In: Transactions of the American Society of Agricultural Engineers. p 1-32.

Nienaber, J. A., and G. L. Hahn. 1989. Cool nighttime temperature and weaning age effects on 3 to 10 week old pigs. Transactions of the American Society of Agricultural Engineers 32:691-695.

Nienaber, J. A., G. L. Hahn, and J. T. Yen. 1987. Thermal environment effects of growing-finishing swine. 1. Growth, feed intake and heat production. Transactions of the American Society of Agricultural Engineers 30:1772-1775.

Nienaber, J. A., and G. LeRoy Hahn. 1984. Effects of water flow restriction and environmental factors on performance of nursery-age pigs. J. Anim. Sci. 59:1423-1429. 


\section{Renaudeau, H. Gilbert, and J. Noblet}

Noblet, J., J. Y. Dourmad, M. Etienne, and J. Le Dividich. 1997. Energy metabolism in pregnant sows and newborn pigs. J. Anim. Sci, 75:2708-2714.

Noblet, J., J. Y. Dourmad, J. Le Dividich, and S. Dubois. 1989. Effect of ambient temperature and addition of straw or alfalfa in the diet on energy metabolism in pregnant sows. Livest. Prod. Sci. 21:309-324.

Noblet, J., and M. Etienne. 1987. Metabolic utilization of energy and maintenance requirements in lactating sows. J. Anim. Sci. 64:774-781.

Noblet, J., H. Fortune, X. S. Shi, and S. Dubois. 1994a. Prediction of net energy value of feeds for growing pigs. J. Anim. Sci. 72:344-354.

Noblet, J., C. Karege, and S. Dubois. 1994b. Prise en compte de la variabilité de la composition corporelle pour la prévision du besoin énergetique et de l'efficacité alimentaire chez le porc en croissance. Journées de la Recherche Porcine en France 26:267-276.

Noblet, J., C. Karege, S. Dubois, and J. van Milgen. 1999. Metabolic utilization of energy and maintenance requirements in growing pigs: effects of sex and genotype. J. Anim. Sci. 77:1208-1216.

Noblet, J., and J. Le Dividich. 1981. Energy Metabolism of the Newborn Pig during the First $24 \mathrm{~h}$ of Life. Neonatology 40:175-182.

Noblet, J., J. Le Dividich, and T. Bikawa. 1985. Interaction between energy level in the diet and environmental temperature on the utilization of energy in growing pigs. J. Anim. Sci. 61:452-459.

Noblet, J., J. Le Dividich, and J. Van Milgen. 2001. Thermal environment and swine nutrition. p 26 in Swine Nutrition. A. J. Lewis and L. L. Southern, eds. CRC Press, Boca Raton London New York Washington, D.C., USA.

Noblet, J., and G. Le Goff. 2001. Effect of dietary fibre on the energy value of feeds for pigs. Anim.Feed.Sci. Tech. 90:35-52.

Omtvedt, I. T., R. E. Nelson, R. L. Edwards, D. F. Stephens, and E. J. Turman. 1971. Influence of heat stress during early, mid and late pregnancy of gilt. J. Anim. Sci. 32:312.

Pettigrew, J. E., S. G. Cornelius, R. L. Moser, T. R. Heeg, H. E. Hanke, K. P. Miller, and C. D. Hagen. 1986. Effects of oral doses of corn oil and other factors on preweaning survival and growth of piglets. J. Anim. Sci. 62:601-612.

Pluske, J. R., I. H. Williams, F. X. Aherne, and M. A. Varley. 1995. Nutrition of the neonatal pig 'The Neonatal Pig, Development and Survival. p 187-235. CAB international, Walligford, UK.

Prunier, A., H. Quesnel, M. Messias de Bragança, and A. Y. Kermabon, 1996. Environmental and seasonal influences on the return-to-oestrus after weaning in primiparous sows: a review. Livest. Prod. Sci. 45:103-110.

Prunier, A., N. M. Soede, H. Quesnel, B. Kemp, J. R. Pluske, J. Le Dividich, and M. W. A. Verstegen. 2003. Productivity and longevity of weaned sows Weaning the pig. Concepts and consequences. p 385-419. Wageningen Academic Publishers, Wageningen, the Netherlands.

Quiniou, N., P. Massabie, and R. Granier. 2000a. Diurnally variation of ambient temperature around 24 or 28 ${ }^{\circ} \mathrm{C}$ : Influence on performance and feeding behavior of growing pigs, Des Moines, Iowa, USA.p 232-239.

Quiniou, N., D. Gaudré, S. Rapp, and D. Guillou. 2000b. Influence de la température ambiante et de la concentration en nutriments de l'aliment sur les performances de lactation de la truie primipare. Journée des Recherches Porcines en France 32:275-282.

Quiniou, N., and J. Noblet. 1999. Influence of high ambient temperatures on performance of multiparous lactating sows. J. Anim. Sci. 77:2124-2134.

Renaudeau, D. 2008. Nutrition of the lactating sows in hot conditions 3rd CLANA congress. Colegio Latinamericano de Nutricion Animal, Cancun, Q. Roo, Mexico 


\section{Effect of climatic environment on feed efficiency in swine}

Renaudeau, D., C. Anais, L. Tel, and J. L. Gourdine. 2010. Effect of temperature on thermal acclimation in growing pigs estimated using a nonlinear function. J. Anim Sci. 88:3715-3724.

Renaudeau, D., Collin, A., Yahav, S. de Basilio, V., Gourdine, J.L. and R.J. Collierl. 2011a. Adaptation to tropical climate and research strategies to alleviate heat stress in livestock production: a review. Animal (doi:10.1017/S1751731111002448).

Renaudeau, D., M. Giorgi, F. Silou, and J. L. Weisbecker. 2006. Effect of breed (lean or fat pigs) and sex on performance and feeding behaviour of group housed growing pigs in a tropical climate. Asian-Australas. J. Anim. Sci. 19:593-601.

Renaudeau, D., J. L. Gourdine, B. A. N. Silva, and J. Noblet. 2008. Nutritional routes to attenuate heat stress in pigs. In: Livestock and Global Climate Change, Hammamet, Tunisia. p 134-138.

Renaudeau, D., J. L. Gourdine, and N. R. St-Pierre. 2011b. A meta-analysis of the effect of high ambient temperature on growing-finishing pigs. J. Anim. Sci. 89:2220-2230.

Renaudeau, D., E. Huc, and J. Noblet. 2007. Acclimation to high ambient temperature in Large White and Caribbean Creole growing pigs. J. Anim. Sci. 85:779-790.

Renaudeau, D., J. Noblet, and J. Y. Dourmad. 2003a. Effect of ambient temperature on mammary gland metabolism in lactating sows. J. Anim. Sci. 81:217-231.

Renaudeau, D., N. Quiniou, S. Dubois, and J. Noblet. 2002. Effect of high ambient temperature and dietary protein level on feeding behaviour of multiparous lactating sows. Anim. Res. 51:227-243.

Renaudeau, D., and J. Noblet. 2001. Effects of exposure to high ambient temperature and dietary protein level on sow milk production and performance of piglets. J. Anim. Sci. 79:1540-1548.

Renaudeau, D., N. Quiniou, and J. Noblet. 2001. Effects of exposure to high ambient temperature and dietary protein level on performance of multiparous lactating sows. J. Anim. Sci. 79:1240-1249.

Renaudeau, D., J. L. Weisbecker, and J. Noblet. 2003b. Effect of season and dietary fibre on feeding behaviour of lactating sows in a tropical climate. Anim. Sci. 77:429-437.

Rinaldo, D. 1989. Influence de la température ambiante sur le métabolisme énergétique et tissulaire et le besoin en lysine du porc en croissance. Mise en évidence de lintérêt d'une température élevée. PhD, Université de Rennes I.

Rinaldo, D., and J. le Dividich. 1991. Assessment of optimal temperature for performance and chemical body composition of growing pigs.Livest. Prod. Sci. 29:61-75.

Rinaldo, D., and J. Le Dividich. 1991. Influence de la température ambiante sur les performances de croissance du porc. Prod. Anim. (Paris) 4:57-65.

Schoenherr, W. D., T. S. Stahly, and G. L. Cromwell. 1989. The effects of dietary fat or fiber addition on yield and composition of milk from sows housed in a warm or hot environment. J. Anim. Sci. 67:482-495.

Shelton, D. P., and M. C. Brumm. 1984. Response of nursery pigs to reduced nocturnal temperatures. ASAE paper $\mathrm{N}^{\circ} 84-4021 \mathrm{St}$. Joseph, MI.

Silva, B. A. N., J. Noblet, J. L. Donzele, R. F. M. Oliveira, Y. Primot, J. L. Gourdine, and D. Renaudeau. $2009 \mathrm{a}$. Effects of dietary protein level and amino acid supplementation on performance of mixed-parity lactating sows in a tropical humid climate. J. Anim Sci. 87:4003-4012.

Silva, B. A. N., A. I. G. Oliveira, J. L. Donzele, H. C. Fernandez, M. L. T. Abreu, J. Noblet, and C. G. V. Nunes. 2006. Effect of floor cooling on performance of lactating sows during summer. Livest. Prod. Sci. 105:176-184.

Silva, B. A. N., R. F. M. Oliveira, J. L. Donzele, H. C. Fernandes, A. L. Lima, D. Renaudeau, and J. Noblet. $2009 \mathrm{~b}$. Effect of floor cooling and dietary amino acids content on performance and behaviour of lactating primiparous sows during summer. Livestock Science 120:25-34. 


\section{Renaudeau, H. Gilbert, and J. Noblet}

Spencer, J. D., R. D. Boyd, R. Cabrera, and G. L. Allee. 2003. Early weaning to reduce tissue mobilization in lactating sows and milk supplementation to enhance pig weaning weight during extrme heat stress. J. Anim. Sci. 81:2041-2052.

Spencer, J. D., A. M. Gaines, G. Rentfrow, W. Cast, J. L. Usry, and G. L. Allee. 2001. Supplemental fat and/or reduced dietary protein crude protein effects on growth performance, carcass characteristics, and meat quality of late finishing barrows reared in controlled hot environment. J. Anim. Sci. 79:66.

Stahly, T. S., and G. L. Cromwell. 1979. Effect of environmental temperature and dietary fat supplementation on the performance and carcass characteristics of growing and finishing swine. J. Anim. Sci. 49:1478-1488.

Stahly, T. S., G. L. Cromwell, and J. R. Overfield. 1981. Interactive effects of season of year and dietary fat supplementation, lysine source and lysine level on the performance of swine. J. Anim. Sci. 53:1269-1277.

Stansbury, W. F., J. J. McGlone, and L. F. Tribble. 1987. Effects of season, floor type, air temperature and snout cooler on sow and litter performance. J. Anim. Sci. 65:1507-1513.

Suriyasomboon, A., N. Lundeheim, A. Kunavongkrit, and S. Einarsson. 2004. Effect of temperature and humidity on sperm production in Duroc boars under different housing systems in Thailand. Livest. Prod. Scí. 89:19-31.

Tokach, M. D., B. Goodband, J. L. Nelssen, and L. J. Kats. 1992. Influence of the weaning weight and growth during the first week post-weaning on subsequent pig performance. Kansas State University Day, report of progress, No. 667.

Turner, L. W., H. J. Monegue, R. S. Gates, and M. D. Lindemann. 1997. Fan, sprinkler, and sprinkler plus fan systems for cooling growing-finishing swine. In: ASAE Annual International Meeting, Minneapolis, Minnesota, USA, 10-14 August, 1997. p 13 pp.

Van der Hel, W., M. W. A. Verstegen, W. Baltussen, and H. Brandsma. 1984. The effect of ambiant temperature on diurnal rhythm in heat production and activity in pigs kept in groups. Int. J. Biometeorol. 28:303-315.

Van Milgen, J., N. Quiniou, and J. Noblet. 2000. Modelling the relation between energy intake and protein and lipid deposition in growing pigs. Anim. Sci. 71:119-130.

Van Wagenberg, A. V., C. M. C. Van de Peet-Schwering, G. P. Binnendijk, and P. J. P. W. Claessen. 2006. Effect of floor cooling on farrowing sow and litter performance: field experiment under Dutch conditions. Transactions of the ASABE 49:1521-1527.

Vanderhaeghe, C., J. Dewulf, S. Ribbens, A. de Kruif, and D. Maes. 2010. A cross-sectional study to collect risk factors associated with stillbirths in pig herds. Anim. Reprod. Sci. 118:62-68.

Varley, M. A. 1995. Introduction. The neonatal pig, development and survival. p 1-16. CAB international, Wallingford, UK.

Verhagen, J. M. F., R. Geers, and M. W. A. Verstegen. 1988. Time taken for growing pigs to acclimate to change in ambient temperature. Neth. J. Agric. Sci. 36:1-10.

West, J. W. 2003. Effects of heat-stress on production in dairy cattle. J. Dairy Sci. 86:2131-2144,

Wettmann, R. P., M. E. Wells, I. T. Omtvedt, C. E. Pope, and E. J. Turman. 1976. Influence of elevated ambient temperature on reproductive performance of boars. J. Anim. Sci. 42:664-669.

Wildt, D., G. Riegle, and W. Dukelow. 1975. Physiological temperature response and embryonic mortality in stressed swine. American Journal of Physiology 229:1471-1475.

Yang, P. G., W. D. Fang, I. T. Yu, S. H. Wang, C. Y. Tsay, W. B. Chung, and M. Rea-Sen Liu. 1996. Pathological studies of abortion, stillbirth and neonatal deaths on a swine herd in Taiwan. Journal of the Chinese Society of Veterinary 22:222-228. 